\title{
Primary Hippocampal Neurons, Which Lack Four Crucial Extracellular Matrix Molecules, Display Abnormalities of Synaptic Structure and Function and Severe Deficits in Perineuronal Net Formation
}

\author{
Maren Geissler, ${ }^{1 \star}$ Christine Gottschling, ${ }^{1 \star}$ Ainhara Aguado, ${ }^{2}$ Uwe Rauch, ${ }^{4}$ Christian H. Wetzel, ${ }^{2,3}$ Hanns Hatt,${ }^{2}$ \\ and Andreas Faissner ${ }^{1}$ \\ ${ }^{1}$ Department of Cell Morphology and Molecular Neurobiology and ${ }^{2}$ Department of Cell Physiology, Ruhr-University, D-44780 Bochum, Germany, \\ ${ }^{3}$ Department of Psychiatry and Psychotherapy, Molecular Neurosciences, University of Regensburg, Regensburg, Germany, and ${ }^{4}$ Department of \\ Experimental Medical Science, Lund-University, Lund, Sweden
}

The extracellular matrix (ECM) of the brain plays crucial roles during the development, maturation, and regeneration of the CNS. In a subpopulation of neurons, the ECM condenses to superstructures called perineuronal nets (PNNs) that surround synapses. Camillo Golgi described PNNs a century ago, yet their biological functions remain elusive. Here, we studied a mouse mutant that lacks four ECM components highly enriched in the developing brain: the glycoproteins tenascin- $\mathrm{C}$ and tenascin- $\mathrm{R}$ and the chondroitin sulfate proteoglycans brevican and neurocan. Primary embryonic hippocampal neurons and astrocytes were cultivated using a cell insert system that allows for co-culture of distinct cell populations in the absence of direct membrane contacts. The wild-type and knock-out cells were combined in the four possible permutations. Using this approach, neurons cultivated in the presence of mutant astrocytes displayed a transient increase of synapses after 2 weeks. However, after a period of 3 weeks or longer, synapse formation and stabilization were compromised when either neuron or astrocyte cell populations or both were of mutant origin. The development of PNN structures was observed, but their size was substantially reduced on knock-out neurons. The synaptic activity of both wild-type and knock-out neurons was monitored using whole-cell patch clamping. The salient observation was a reduced frequency of IPSCs and EPSCs, whereas the amplitudes were not modified. Remarkably, the knock-out neuron phenotypes could not be rescued by wild-type astrocytes. We conclude that the elimination of four ECM genes compromises neuronal function.

\section{Introduction}

Research over the past decade has shed light on the complexity of neuron-glia interactions, which reaches far beyond structural support and the delivery of nutrients (Perea et al., 2009; Di Castro et al., 2011; Porto-Pazos et al., 2011). Astrocytes and neurons form a tripartite synapse (Haydon, 2001; Slezak and Pfrieger, 2003; Perea et al., 2009) and glia affect synaptic strength and plasticity (Beattie et al., 2002; Theodosis et al., 2008). Astrocytes

Received June 29, 2012; revised Feb. 15, 2013; accepted March 26, 2013.

Author contributions: M.G., C.H.W., H.H., and A.F. designed research; M.G., C.G., and A.A. performed research; U.R. contributed unpublished reagents/analytic tools; M.G., C.G., A.A., C.H.W., H.H., and A.F. analyzed data; M.G., C.H.W., H.H., and A.F. wrote the paper.

This work was supported by the Research Department of Neuroscience of the Ruhr-University Bochum, the graduate training college GRK 746, the research school of the Ruhr University Bochum (GSC98/1), and the priority program SSP 1172 "Glia and Synapse" (Fa 159/14-1,2,3) of the German Research Foundation. We thank Dr. Morawski for advice concerning anti-aggrecan antibodies.

The authors declare no competing financial interests.

*M.G. and C.G. contributed equally to this work.

Correspondence should be addressed to Prof. Dr. Andreas Faissner, Faculty of Biology and Biotechnology, Department of Cell Morphology and Molecular Neurobiology, Building NDEF 05/594, Universitaetsstrasse 150, RuhrUniversity, D-44801 Bochum Germany. E-mail: andreas.faissner@rub.de.

DOI:10.1523/JNEUROSCI.3275-12.2013

Copyright $\odot 2013$ the authors $\quad 0270-6474 / 13 / 337742-14 \$ 15.00 / 0$ secrete soluble factors such as neurotrophins (Elmariah et al., 2005; Cahoy et al., 2008), cholesterol (Mauch et al., 2001), and extracellular matrix (ECM) molecules that were shown to be mediators of these mechanisms (Gomes et al., 2001; Lafon-Cazal et al., 2003; Carulli et al., 2005; Frischknecht et al., 2009; Faissner et al., 2010; Pyka et al., 2011b). The neural ECM includes the chondroitin sulfate proteoglycans (CSPGs) of the lectican family, as well as glycoproteins such as the tenascins. Mice deficient for tenascin-C (Tnc) or tenascin-R (Tnr) display impaired LTP (Evers et al., 2002) and diminished plasticity (Bukalo et al., 2001; Saghatelyan et al., 2001; Cybulska-Klosowicz et al., 2004; Bukalo et al., 2007). LTP is also reduced in the brevican knock-out mouse without, however, compromising memory development (Brakebusch et al., 2002). Interestingly, both tenascin mutants develop a phenotype concerning the inhibitory circuitry of the cortex (Saghatelyan et al., 2000; Nikonenko et al., 2003; Irintchev et al., 2005).

The tenascins and the CSPGs are components of a specialized form of the matrix that is tightly associated with the neuronal cell body and proximal dendrites of Parvalbumin-positive interneurons (Wintergerst et al., 1996) and constructs the perineuronal net (PNN; Celio et al., 1998; Brückner et al., 2000; Carulli et al., 
2006), which was first described by Camillo Golgi (Celio et al., 1998). Until recently, the functions of the PNN had remained enigmatic (Gogolla et al., 2009; Carulli et al., 2010; Kwok et al., 2010; Kwok et al., 2011), but are now considered to be important during the maturation and maintenance of neuronal networks (Pizzorusso et al., 2002; Dityatev et al., 2007; Gogolla et al., 2009). Therefore, the enzymatic digestion of PNNs leads to the prolongation of the plasticity period (Pizzorusso et al., 2002; Gogolla et al., 2009), which is relevant in the realm of regeneration after CNS injury (Kwok et al., 2011).

To understand the molecular mechanisms of PNN formation and functions on the cellular and synaptic level, we took advantage of a quadruple knock-out mutant mouse that lacks the glycoproteins Tnc and Tnr and the CSPGs brevican and neurocan. Primary hippocampal neurons were analyzed on the morphological and the physiological level (Pyka et al., 2011a; Pyka et al., 2011b). We show here that the elimination of four ECM genes has a strong impact on PNN number and complexity in vitro, and this is accompanied by a significant decrease of miniature postsynaptic current frequency and changes of synapse formation. Our results reveal novel insights concerning the roles of the ECM in synapse development and function.

\section{Materials and Methods}

Ethical standards and animal housing. All experiments were approved by the animal care and utilization committees of the Ruhr-University Bochum and were performed in accordance with the Society for Neuroscience and the German guidelines.

Animals of either sex were reared under standardized housing conditions with $24 \mathrm{~h}$ light/dark cycle and regulated humidity. Food and water were available ad libitum. A colony of the quadruple knock-out mouse (Rauch et al., 2005) is kept in the animal house of the Faculty for Biology and Biotechnology of the Ruhr University Bochum.

Immunological reagents. The following polyclonal antibodies (all rabbit, except for the anti-neurocan antibody from R\&D Systems) were used: anti-neurocan (1:200, prepared by U. Rauch, Lund, Sweden; Haas et al., 1999 or sheep anti-neurocan, catalog \#AF 5800, 1:100; R\&D Systems was used, with comparable results), anti-brevican (1:300; Seidenbecher et al., 1995), anti-aggrecan (1:2000; Millipore), anti-Tnc (batch KAF 14, 1:200; Faissner and Kruse, 1990), anti-bassoon (kind gift from E. Gundelfinger, 1:2000; tom Dieck et al., 1998), anti-neurofilament 200 (NF-200, 1:300; Sigma-Aldrich), anti-GFAP (1:300, Sigma-Aldrich), and anti-caspase3 (1:300; Sigma-Aldrich).

The following mouse monoclonal antibodies were used: antipostsynaptic density protein 95 (PSD95, 1:500; Calbiochem), anti- $\beta$ IIItubulin (1:200 for ICC, 1:750 in WB; Sigma-Aldrich), anti-Tnr (clone 23-14, 1:200, kind gift from F.G. Rathjen; Rathjen et al., 1991), antiglutamic acid decarboxylase 65 and 67 (GAD 65/67, 1:1000; Stressgen), anti-vesicular glutamate transporter (vGlut1, 1:1000; Medimabs), antigephyrin (1:500; Synaptic Systems), anti-aggrecan (1:800; Serotec), O4 (1:30, clone 81; Sommer and Schachner, 1981; Czopka et al., 2009), anti-Nestin (1:300; Millipore). Wisteria floribunda agglutinin (WFA, 1:100; Sigma-Aldrich) was used for the detection of PNNs.

All secondary antibodies were purchased from Dianova and subclass specific CY2, CY3, or CY5 anti-rabbit or anti-mouse and streptavidincoupled CY2 or CY3 were used to reveal primary antibody or WFA binding. Cell nuclei were detected with bisbenzimide (Hoechst 33528, 1:100,000; Sigma-Aldrich).

Cell culture. Neurons and astrocytes were cultivated in an indirect co-culture assay without direct contact, but sharing the same defined medium (Pyka et al., 2011a). Both cell types were derived as described previously (Goslin and Banker, 1989; Kaech and Banker, 2006; Michele and Faissner, 2009) with minor modifications indicated below.

For the preparation of astrocytes, postnatal mice of either sex (P1-P3, NMRI, and quadruple knock-out mice; Rauch et al., 2005) were decapitated and cortices were removed and separated from the meninges and surrounding tissue. After enzymatic digestion of the cortices with $0.1 \%$ w/v papain (Worthington) in MEM (Invitrogen) for $1 \mathrm{~h}$, the tissue was mechanically triturated and centrifuged. The resulting cell pellet was resuspended in $1 \mathrm{ml}$ of astrocyte medium (DMEM; Invitrogen) with 10\% $\mathrm{v} / \mathrm{v}$ horse serum (Biochrom) and $1 \% \mathrm{v} / \mathrm{v}$ penicillin/streptomycin (Invitrogen). The single-cell suspension obtained was added to $10 \mathrm{ml}$ of astrocyte medium in T-75 flasks (Nunc) precoated with $10 \mu \mathrm{g} / \mathrm{ml}$ poly-D-Lysine (Sigma-Aldrich) at a density of four cortices per flask. The cells were grown for at least $7 \mathrm{~d}$ in vitro (DIV) at $37^{\circ} \mathrm{C}$ with $6 \% \mathrm{v} / \mathrm{v} \mathrm{CO}_{2}$, and a complete medium change was performed every second day. To get rid of progenitor and oligodendrocyte precursor cells and to achieve a confluent layer of astrocytes, flasks were shaken overnight on an orbital shaker (New Brunswick Scientific) at $37^{\circ} \mathrm{C}$ and $250 \mathrm{rpm}$, followed by the addition of $20 \mu \mathrm{M}$ cytosine$1-\beta$-D arabinofuranoside (AraC, Sigma-Aldrich) for $2 \mathrm{~d}$. Twenty-four to $48 \mathrm{~h}$ before the preparation of neurons was undertaken (see below), astrocytes were replated in cell culture inserts (pore size $0.4 \mu \mathrm{m}$; BD Biosciences) via enzymatic digestion with trypsin $(0.25 \% \mathrm{w} / \mathrm{v}$ trypsin with EDTA in MEM, both from Invitrogen) at a density of 25,000 cells per insert.

Hippocampal neurons were derived from embryonic mice (E15.5) of time pregnant NMRI and quadruple knock-out mice of either sex (Rauch et al., 2005). Hippocampi were dissected and separated from meninges and surrounding tissue before enzymatic digestion with $0.25 \% \mathrm{w} / \mathrm{v}$ trypsin (Invitrogen) in MEM (Invitrogen) for $15 \mathrm{~min}$. After mechanical trituration and centrifugation, the resulting cell pellet was resuspended in hippocampus medium containing MEM (Invitrogen), $10 \mathrm{~mm}$ sodium pyruvate (Sigma-Aldrich), 0.1\% w/v ovalbumin (Sigma-Aldrich), and $2 \% \mathrm{v} / \mathrm{v}$ B27 (Invitrogen). Afterward, 1200 cells were plated out at a low density of 3500 cells $/ \mathrm{cm}^{2}$ on glass coverslips (Thermo Scientific) coated with $15 \mu \mathrm{g} / \mathrm{ml}$ polyornithin (Sigma-Aldrich) in 24-well plates (BD Biosciences). Hippocampal neurons were cultivated at $37^{\circ} \mathrm{C}$ and $6 \% \mathrm{v} / \mathrm{v} \mathrm{CO}_{2}$ in a humidified incubator.

After an adherence time of $2 \mathrm{~h}$, the cell culture inserts with astrocytes were added and the astrocyte medium was replaced with hippocampus medium.

Four different genotype combinations (wilde-type: ${ }^{\text {w/w }}$, knock-out: ${ }^{\text {ko/ko }}$ ) of neurons (N) and astrocytes (A) were used in the study: both cells from wild-type: $A^{\mathrm{w} / \mathrm{w}} \mid \mathrm{N}^{\mathrm{w} / \mathrm{w}}$, both cells from knock-out $\mathrm{A}^{\mathrm{ko} / \mathrm{ko}} \mid \mathrm{N}^{\mathrm{ko} / \mathrm{ko}}$, astrocytes from knock-out and neurons from wild-type $A^{\mathrm{ko} / \mathrm{ko}} \mid \mathrm{N}^{\mathrm{w} / \mathrm{w}}$, and astrocytes from wild-type and neurons from knock-out $\mathrm{A}^{\mathrm{w} / \mathrm{w}} \mid \mathrm{N}^{\mathrm{ko} / \mathrm{ko}}$.

The cell density in the different culture conditions was estimated by counting the numbers of neurons in at least five visual fields chosen at random after 14 and 21 DIV. No significant difference in cell counts and thus survival was found.

Electrophysiology. Primary embryonic (E15.5) hippocampal neurons of the four cell culture combinations were recorded in the whole-cell configuration using the patch-clamp technique. Membrane voltage was controlled and currents were measured using an L/M-EPC7 patch-clamp amplifier (List). Borosilicate glass (GB150EFT-10; Science Products) pipettes were pulled with a horizontal pipette puller (DMZ Universal Puller; Zeitz Instruments). The patch pipettes showed resistances ranging from 3 to $6 \mathrm{M} \Omega$ and hippocampal neurons were voltage clamped at -60 $\mathrm{mV}$. Signals were filtered from 1.0 to $3.0 \mathrm{kHz}$. Series resistance and cell capacitance were compensated before the recordings.

The patch pipettes were filled with an intracellular solution containing the following (in mM): $140 \mathrm{KCl}, 2 \mathrm{MgCl}_{2}, 11 \mathrm{EGTA}, 1 \mathrm{CaCl}_{2}, 2 \mathrm{HEPES}$, pH 7.4, 290-310 mOsm. The standard bath solution contained the following (in mM): $145 \mathrm{NaCl}, 5 \mathrm{KCl}, 2 \mathrm{CaCl}_{2}, 1 \mathrm{MgCl}_{2}, 10 \mathrm{HEPES}, \mathrm{pH} 7.3$, $\sim 290-310 \mathrm{mOsm}$ and all recordings were performed at room temperature $\left(20-24^{\circ} \mathrm{C}\right)$.

For the measurements of miniature postsynaptic currents (mPSCs) pharmacological isolation was required. Picrotoxin $(150 \mu \mathrm{M})$ was added to bath solutions of all four cell culture combinations to block GABA-A receptor-mediated currents, which allowed the recording of miniature EPSCs (mEPSCs). The AMPA- and kainate-receptor-mediated current blocker 6,7-dinitroquinoxaline-2,3-dione (DNQX, $10 \mu \mathrm{M}$ ) and the voltage-gated sodium currents blocker tetrodotoxin $(1 \mu \mathrm{M})$ were added in the bath solutions of all four cell combinations for the measurement of miniature IPSCs (mIPSCs).

For the analysis of PNN-bearing neurons, the PNNs were stained on living cultures by applying fluorescent dye-coupled WFA (1:50; Vector 
Laboratories) for $30 \mathrm{~min}$ in the incubator at $37^{\circ} \mathrm{C}$. After three washes with PBS, the PNNs were located by immunofluorescence on an inverted microscope. Strongly positive neurons were patched and recorded and the results were compared with those obtained on unstained cultures.

Acquisition of the postsynaptic events was performed with Pulse software (HEKA Instruments). After conversion of the data in the right format (using the ABF utility of the mini-analysis program Synaptosoft version 6.0.3), specific functional parameters of mEPSCs and mIPSCs, such as rise and decay time (kinetic), amplitude, charge (which represents the area under the peak of the postsynaptic event), and frequency were analyzed with Synaptosoft 6.0.3. Only cells with consistent gigaseal and series resistances throughout the experiment were included in the analysis.

Immunocytochemistry. For immunofluorescent staining of neurons, the medium was carefully aspirated and the cells were fixed with $4 \% \mathrm{w} / \mathrm{v}$ paraformaldehyde (Sigma-Aldrich) for $10 \mathrm{~min}$, rinsed with PBS, and washed twice with PBS/T (PBS with $0.1 \%$ v/v Triton X-100; SigmaAldrich). Primary antibodies were diluted in PBS/T and incubated for 30 min, followed by three washes with PBS/A (PBS with $0.1 \%$ w/v BSA; Sigma-Aldrich). Secondary antibodies were diluted in PBS/A and incubated for $30 \mathrm{~min}$. Thereafter, the cells were washed twice with PBS and once with Milli-Q water (Millipore). Finally, the cells on microscope slides were covered with Immumount (slides and embedding medium were both from Thermo Fischer Scientific).

For the immunocytochemical detection of synaptic puncta, the cells were fixed as described above. The fixation of cells was followed by three washing steps with PBS, 15 min incubation with 25 mm glycin (SigmaAldrich), and $1 \mathrm{~h}$ blocking with a blocking buffer containing $10 \% \mathrm{v} / \mathrm{v}$ horse serum (Biochrom) and 0.1\% v/v Triton X-100 (Sigma-Aldrich). Primary antibodies in blocking buffer were incubated for $60 \mathrm{~min}$, followed by three washing steps with PBS and secondary antibody incubation in blocking buffer for $60 \mathrm{~min}$. Afterward, the coverslips were washed three times with PBS and rinsed with Milli-Q water before covering in Immumount on microscope slides (both Thermo Scientific).

Western blotting. For Western blotting, the culture protocol was scaled up to 6-well plates with corresponding inserts and 1.5-2.0 $\times 10^{5}$ neurons per well. After a cultivation time of 14 or $21 \mathrm{DIV}$, neurons were washed twice with ice-cold PBS after the medium was carefully aspirated. Thereafter, the cells were collected on ice with ice-cold lysis buffer $(50 \mathrm{~mm}$ Tris/HCl, pH 7.4, 150 mm NaCl, 5 mm EDTA, 5 mm EGTA, 1\% v/v Triton $\mathrm{X}-100,0.1 \% \mathrm{w} / \mathrm{v} \mathrm{Na}$-deoxycholate, and $0.1 \% \mathrm{w} / \mathrm{v}$ SDS). Proteins lysates were cleared via centrifugation at $4^{\circ} \mathrm{C}$ and $16,000 \times g$ for $20 \mathrm{~min}$. The protein concentration of the probes was determined using a protein concentration kit (Pierce) and the tubes were stored at $-20^{\circ} \mathrm{C}$. For SDSPAGE, $20 \mu \mathrm{g}$ of proteins from each probe were separated on a $7 \%$ polyacrylamide gel under reducing conditions. Next, protein bands were transferred to a polyvinylidene fluoride (PVDF) membrane (Roth). Membranes were blocked by incubation with $5 \% \mathrm{w} / \mathrm{v}$ milk powder in TBST (25 mм Tris-HCl, $150 \mathrm{~mm} \mathrm{NaCl,} 0.05 \%$ v/v Tween 20, pH 7.4). For immunodetection, the PVDF membranes were incubated overnight with primary antibodies (see above) in $5 \% \mathrm{w} / \mathrm{v}$ milk powder in TBST and the next day, the appropriate secondary HRP-conjugated antibodies were incubated for $1 \mathrm{~h}$ and signals were detected using enhanced electrochemiluminescence (Pierce).

Microscopy. The immunostained neurons were examined using an Axioplan 2 microscope with UV epifluorescence (Zeiss). Images were photographed with a digital camera (AxioCam MRm; Zeiss) and documented using AxioVision 4.5 software (Zeiss). Images of neurons immunostained for the detection of synaptic puncta were examined using the confocal laser-scanning microscope LSM 510 Meta (Zeiss). Gain and threshold were not changed during the experiments. $Z$-stacks were taken with a $0.25 \mu \mathrm{m}$ interval and an overlay of the resulting single pictures was performed afterward.

Quantifications and statistical analyses. Quantification of the intensity of the protein bands obtained in Western blots was performed using ImageJ software (http://rsbweb.nih.gov/ij/) and results were normalized with reference to the appropriate $\beta$ III-tubulin bands.

The average fraction of neurons that was scored immunopositive for a given ECM component was determined by evaluating at least 100 neu- rons $(n)$ chosen at random per experiment $(N)$ and at least three independent experiments were assessed. The neuronal cultures were also examined for the expression of the glial markers O4 (for oligodendrocytes), nestin, and GFAP.

Synaptic puncta were determined by staining the hippocampal neuron cultures after the time periods indicated with antibodies against Bassoon and PSD-95, presynaptic and postsynaptic markers, respectively, as described previously (Pyka et al., 2011b). For the identification of inhibitory synapses, antibodies to the inhibitory neurotransmitter uptake system and to the scaffolding protein gephyrin were used to tag the presynapse and postsynapse, respectively. Coincidence of presynaptic and postsynaptic labeling was valued as indicating a structural synapse (Pyka et al., 2011a).

For analysis, 40 neurons per condition in a given experiment were sampled at random for quantification of puncta. This design yielded up to 160 values per experiment, including the different co-culture combinations, as follows: $A^{\mathrm{w} / \mathrm{w}}\left|\mathrm{N}^{\mathrm{w} / \mathrm{w}}, \mathrm{A}^{\mathrm{w} / \mathrm{w}}\right| \mathrm{N}^{\mathrm{ko} / \mathrm{ko}}, \mathrm{A}^{\mathrm{ko} / \mathrm{ko}} \mid \mathrm{N}^{\mathrm{w} / \mathrm{w}}$, and $\mathrm{A}^{\mathrm{ko} / \mathrm{ko}} \mid$ $\mathrm{N}^{\mathrm{ko} / \mathrm{ko}}$. The average number of puncta was calculated for each marker of the $\mathrm{A}^{\mathrm{w} / \mathrm{w}} \mid \mathrm{N}^{\mathrm{w} / \mathrm{w}}$ combination and defined as control condition (Puncta $\mathrm{ctrl}_{\mathrm{w}}$ ). Because the number of puncta is influenced by a variety of parameters, we determined the percent increase or percent decrease of the distinct categories of puncta to compare independent experiments.

The increments were calculated with reference to the average number of the $\mathrm{A}^{\mathrm{w} / \mathrm{w}} \mid \mathrm{N}^{\mathrm{w} / \mathrm{w}}$ combination (Puncta ${ }_{\mathrm{ctrl}}$ ). The percent increase or percent decrease was determined for each single measurement according to the equation $\left[\left(\right.\right.$ Puncta $_{\text {Test }}-$ Puncta $\left._{\mathrm{Ctrl}} / \mathrm{Puncta}_{\mathrm{Ctrl}}\right) \times$ 100]. This analysis was also performed for each single count determined in the control situation, which revealed the scatter of values in this condition and allowed for comparative statistical assessment. Because three sets of puncta were investigated per neuron, this strategy resulted in up to 480 values per experiment and time point and up to 1440 values for three independent experiments. When synapse formation on PNN-bearing neurons was evaluated, this strategy was limited to the WFApositive subset of neurons.

For the detection of immunopositive and PNN-bearing neurons, cells were randomly chosen under the microscope and the percentage of immunopositive neurons from 100 Hoechst-positive cells was counted per condition. At least three independent experiments were analyzed.

The intensity of the PNN staining was quantified using a macro for pixel detection in ImageJ. The size of the PNN structures was assessed by determining the average number of pixels per net in a sample of PNNbearing neurons. Synaptic puncta were counted using the punctaanalyzer plug-in from Barry Wark (licensed under http://www.gnu. org/copyleft) for ImageJ. We verified that this semiautomatic analysis led to results that are similar to those we have obtained by visual counting.

The number of pixels per puncta was quantified on all puncta detected along a dendrite chosen at random for the $\mathrm{A}^{\mathrm{w} / \mathrm{w}} \mid \mathrm{N}^{\mathrm{w} / \mathrm{w}}$ combination and the $\mathrm{A}^{\mathrm{ko} / \mathrm{ko}} \mid \mathrm{N}^{\mathrm{ko} / \mathrm{ko}}$ condition. According to this criterion, the size of puncta under the different culture conditions was comparable. Therefore, the differences in synapse umbers could not be explained by shifts in synapse size.

Data are generally given as mean \pm SEM. We performed ANOVA with a significance level set at $p \leq 0.05$. Subsequent pairwise comparisons were done with Student's $t$ test, and Scheffe's post hoc test was used for multiple comparisons.

\section{Results}

Primary hippocampal neurons were cultivated in indirect coculture with astrocytes, allowing for the continuous exchange of molecules between both cell types via the shared defined medium. In this setting, we focused on the contribution of ECM molecules to neuronal development and synapse and PNN formation using a quadruple matrix knock-out mouse (Rauch et al., 2005). 
A

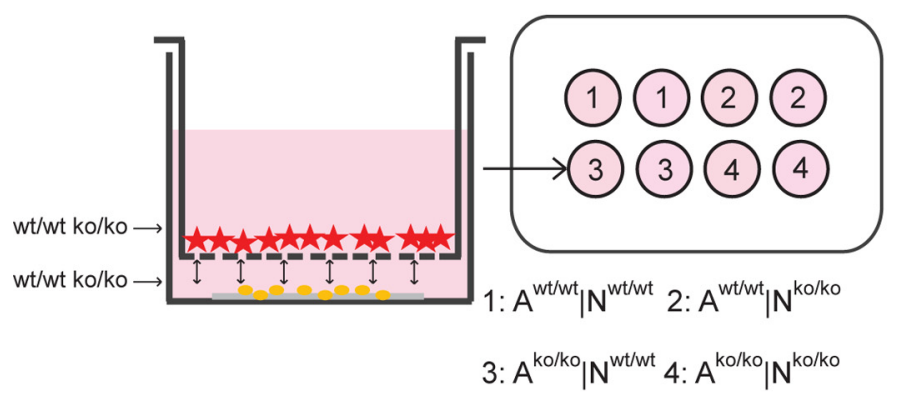

B

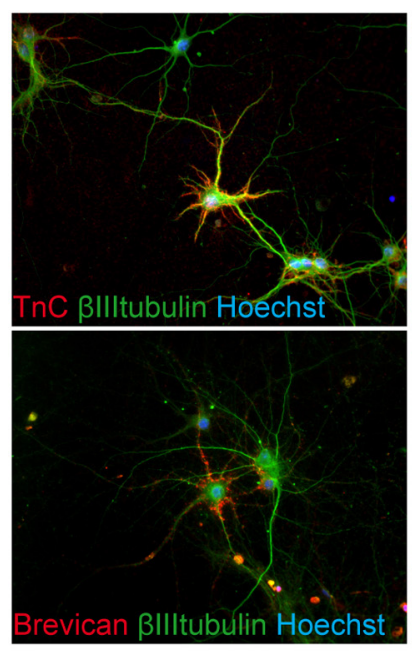

D

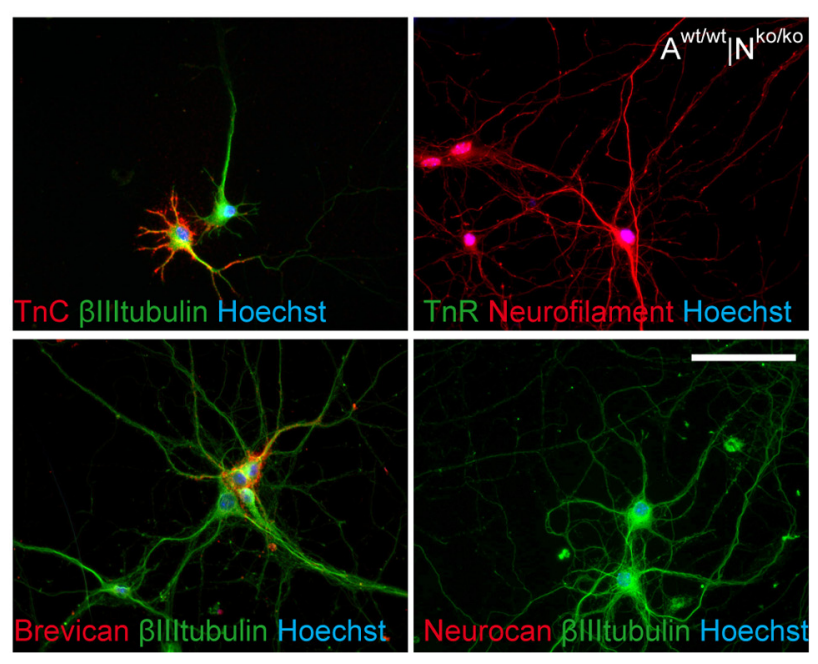

$\mathbf{F}$

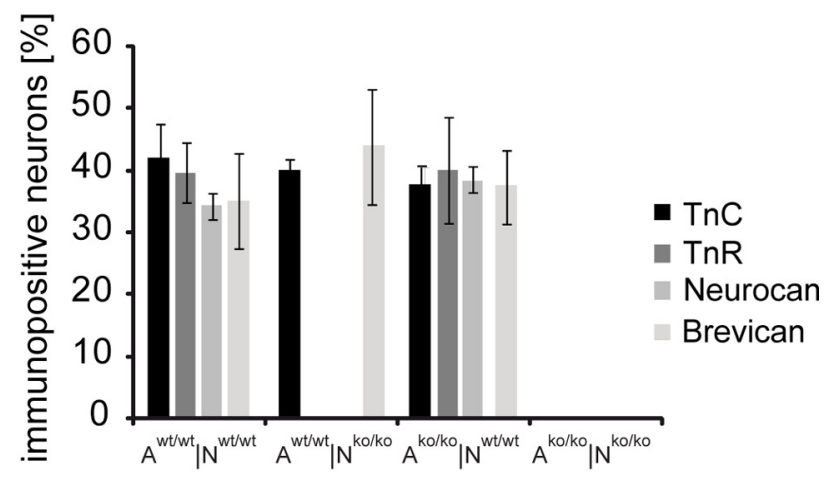

C

Genotype astrocytes (A) and neurons (N)

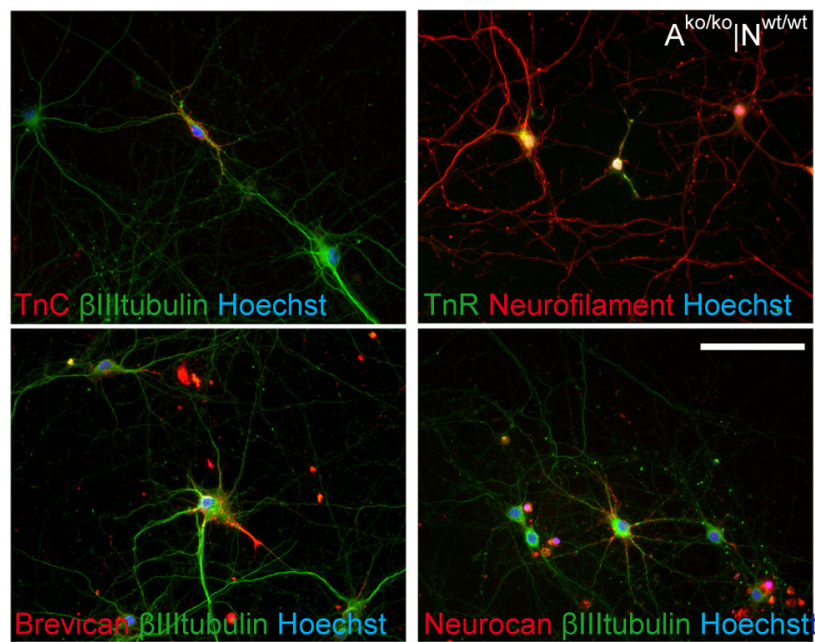

E
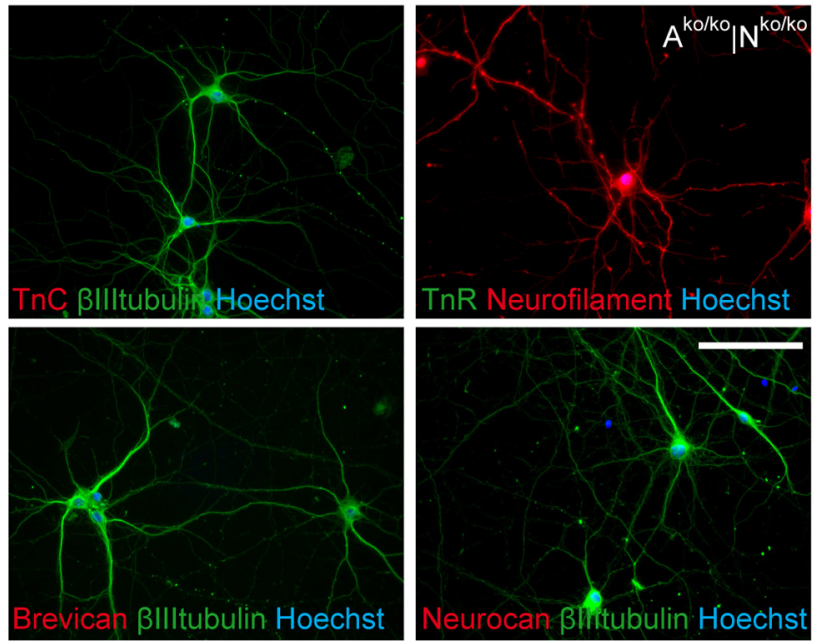

Figure 1. Neuron-astrocyte co-culture setup and the expression of ECM molecules in vitro. $\boldsymbol{A}$, Scheme of the indirect neuron-astrocyte co-culture setup. Astrocytes (red asterisk) were grown in a cell culture insert with a permeable membrane facing the neurons (yellow dots) and sharing the same, defined medium. The four neuron-astrocyte (N/A) genotype combinations used are indicated (1-4). $\boldsymbol{B}-\boldsymbol{E}$, Immunofluorescent stainings of neurons co-cultured with astrocytes after $14 \mathrm{DIV}$ in the different combinations with antibodies against Tnc, Tnr, brevican, and neurocan. Scale bar, 50 $\mu \mathrm{m}$. $\boldsymbol{F}$, Quantification of the staining. Scale bars represent the average fraction \pm SEM. At least 100 neurons chosen at random were assessed per combination and 3 independent experiments were performed $(N=3, n \geq 400)$.

\section{Primary quadruple knock-out neurons and the expression} pattern of the ECM in vitro

To determine the biological role of the ECM, primary hippocampal neurons and cortical astrocytes from the quadruple knockout mouse lacking the genes for Tnc, Tnr, brevican, and neurocan (Rauch et al., 2005) were cultivated in a co-culture assay. Wildtype or knock-out primary neurons or astrocytes were combined in the four possible permutations (Fig. 1A). The cells shared the defined medium, but had no direct membrane-mediated contact, as indicated in the scheme (Fig. 1A). Neurons developed complex networks and survived for at least 21 DIV in this setup (Fig. $1 B-E)$. Neurons derived from mutant hippocampi appeared normal according to morphology and immunocytochemical stainings for $\beta$ III-tubulin or neurofilament (Fig. $1 B-E$ ). Furthermore, 
Table 1. Percentage of immunopositive neurons in the four different cell insert co-culture combinations

\begin{tabular}{lllll}
\hline & $\beta$ III-tubulin & Nestin & GFAP & 04 \\
\hline $\mathrm{A}^{\mathrm{wt} / \mathrm{wt}} \mid \mathrm{N}^{\mathrm{wt} / \mathrm{wt}}$ & $96 \pm 0,06 \%$ & $1 \pm 0 \%$ & $1 \pm 0 \%$ & $0 \pm 0 \%$ \\
$\mathrm{~A}^{\mathrm{ko} / \mathrm{ko}} \mid \mathrm{N}^{\mathrm{wt} / \mathrm{wt}}$ & $96 \pm 0,03 \%$ & $0 \pm 0 \% *$ & $1 \pm 0 \%$ & $0 \pm 0 \%$ \\
$\mathrm{~A}^{\mathrm{wt} / \mathrm{wt}} \mid \mathrm{N}^{\mathrm{ko} / \mathrm{ko}}$ & $94 \pm 0,07 \%$ & $1 \pm 0 \%$ & $1 \pm 0 \%$ & $0 \pm 0 \%$ \\
$\mathrm{~A}^{\mathrm{ko} / \mathrm{ko}} \mid \mathrm{N}^{\mathrm{ko} / \mathrm{ko}}$ & $90 \pm 0,12 \%$ & $0 \pm 0 \% *$ & $1 \pm 0 \%$ & $0 \pm 0 \%$ \\
\hline
\end{tabular}

The table displays the percent-fraction of cells positive for a given marker in the neuronal cultures, as indicated. At least $n>1200$ cells identified according to the nuclear label were counted per condition and at least 3 independent experiments $(N=3)$ were carried out. No significant proliferation of glial contaminants could be recorded in the neuronal cultures after 7 DIV. Note that a small fraction of cells, possibly stem/progenitor cells, was not positive for any of the standard markers.

neither the survival nor the viability was compromised (data not shown). In a study published earlier, we have documented that, after an initial loss, neuron numbers remain stable over a period of up to 3 weeks. Furthermore, no astrocytes were detectable in the neuron monolayer under these conditions (Geissler and Faissner, 2012). This may be due to the fact that the hippocampi were collected and dissected at E15.5, before the major phase of gliogenesis, and plated at low density (3500 neurons $/ \mathrm{cm}^{2}$ ) in the absence of serum, a known stimulator of astrocyte proliferation (Table 1). In this regard our model differs from other systems in which the proliferation of astrocytes in mixed cortical cultures plated at higher density $\left(7 \times 10^{5}\right.$ cells/well $)$ has to be suppressed by the addition of proliferation inhibitors such as AraC (Giamanco and Matthews, 2012).

We also investigated the expression of the ECM molecules Tnc, Tnr, brevican, and neurocan under control conditions in which the cells in both compartments were derived from wildtype tissue. We found a strong extracellular staining pattern of these ECM components after 14 DIV (Fig. 1B). Most of the immunoreactivity was detectable around the soma and proximal dendrites, and in some areas, a substrate staining was visible. The brevican expression pattern tended to be enhanced around one individual neurite (Fig. $1 B$, bottom left). Interestingly, the combination of wild-type neurons with astrocytes derived from the knock-out cortices (Fig. 1C) yielded strong staining of the four ECM components detectable around the neurons. This suggests that the neuronal culture by itself may be capable of ECM expression under particular conditions. Tnc is expressed in hippocampal neurons under certain conditions (Ferhat et al., 1996a). Expression of brevican, neurocan, aggrecan, and Tnr on the protein and message level has been reported in perineuronal-netbearing large excitatory deep cerebellar nuclei neurons and in interneurons of the molecular layer of the cerebellum (Carulli et al., 2006). It is noteworthy that brevican showed a tendency to accumulate around one selected process (Fig. 1C, bottom left), which may correspond to the axon initial segment (John et al., 2006; Hedstrom et al., 2007). In cultures in which both cell types were derived from the mutant, no immunoreactivity whatsoever could be detected, confirming the absence of Tnc, Tnr, brevican, and neurocan.

In the reverse experiment, in which ECM-deficient neurons were co-cultivated with wild-type astrocytes, Tnc and the distinct brevican expression pattern (Fig. 1D) were still visible. In contrast, Tnr and neurocan were not detectable in primary mutant neurons despite the presence of wild-type astrocytes. It appeared therefore that astrocytes contributed Tnc and brevican, whereas Tnr and neurocan seemed to be absent from the neuronal monolayer. The quantification of immunopositive neurons in the different neuron-astrocyte combinations (Fig. $1 F$ ) revealed that the four ECM molecules were expressed in the following cellular fractions: $\mathrm{A}^{\mathrm{w} / \mathrm{w}} \mid \mathrm{N}^{\mathrm{w} / \mathrm{w}}$ : Tnc: $42 \pm 5 \%$, Tnr: $40 \pm 5 \%$, neurocan: $34 \pm 2 \%$, and brevican accumulated in around $35 \pm 8 \%$. $\mathrm{A}^{\mathrm{ko} / \mathrm{ko}}$ $\mathrm{N}^{\mathrm{w} / \mathrm{w}}$ : Tnc: $38 \pm 4 \%$, Tnr: $40 \pm 9 \%$, neurocan: $38 \pm 2 \%$, brevican: $38 \pm 6 \%$. These numbers compare well with earlier reports describing a continuous increase of the fraction of hippocampal neurons displaying brevican and hyaluronan signals from $2 \%$ to 97\% positive neurons after 10 and 21 DIV, respectively (John et al., 2006; Frischknecht et al., 2009). Overall, the cultivation of a relative minority of neurons in the presence of a large excess of astrocytes in shared culture medium favors the accumulation of weakly interacting ECM constituents on the neuronal surface. Differences in the numbers of immunopositive neurons observed may relate to the specific designs of the culture systems, for example, the variation of the physical distance between astrocytes and neurons or the relative concentration of ECM components in the culture medium.

When the cells in both compartments stemmed from the mutant $\left(\mathrm{A}^{\mathrm{ko} / \mathrm{ko}} \mid \mathrm{N}^{\mathrm{ko} / \mathrm{ko}}\right)$, none of the neurons expressed any of the ECM molecules under study, as indicated above. In knock-out neurons cultivated with wild-type astrocytes $\left(\mathrm{A}^{\mathrm{w} / \mathrm{w}} \mid \mathrm{N}^{\mathrm{ko} / \mathrm{ko}}\right)$, we found $40 \pm 2 \%$ of neurons accumulating Tnc and $44 \pm 9 \%$ exposing brevican, whereas neurocan and Tnr were not detectable. The absence of neurocan was not expected, because reactive astrocytes in vitro express this CSPG and release it into the culture medium (Asher et al., 2000; Susarla et al., 2011). However, we confirmed the finding using independent batches of antibodies, showing that the knock-out neurons lose the ability to bind wildtype astrocyte-derived neurocan strongly to their surface.

\section{Electrophysiological recordings show a reduced frequency of miniature postsynaptic currents after 14 and 21 DIV}

Recent studies have demonstrated that mice deficient in ECM molecules such as Tnr (Bukalo et al., 2001; Saghatelyan et al., 2004) and Tnc display an impairment of LTP (Evers et al., 2002). To determine whether the Tnc/Tnr/brevican/neurocan quadruple knock-out resulted in changes of neuronal physiology, we performed whole-cell patch-clamp recordings in neurons grown for 14 and 21 DIV and analyzed all possible knock-out/wild-type combinations under astrocyte-neuron co-culture conditions (Fig. 2A). In our study, mEPSCs or mIPSC elicited by the release of a single vesicle of neurotransmitter in the absence of presynaptic stimuli were recorded. The addition of specific ion channel blockers and receptor antagonists (tetrodotoxin, picrotoxin, and DNQX) allowed for the pharmacological isolation of mEPSCs or mIPSCs. We used astrocyte/neuron co-cultures grown for 14 DIV in the $A^{\mathrm{w} / \mathrm{w}}\left|\mathrm{N}^{\mathrm{w} / \mathrm{w}}, \mathrm{A}^{\mathrm{w} / \mathrm{w}}\right| \mathrm{N}^{\mathrm{ko} / \mathrm{ko}}, \mathrm{A}^{\mathrm{ko} / \mathrm{ko}} \mid \mathrm{N}^{\mathrm{w} / \mathrm{w}}$, and $\mathrm{A}^{\mathrm{ko} / \mathrm{ko}} \mid$ $\mathrm{N}^{\mathrm{ko} / \mathrm{ko}}$ combinations and observed that neither the kinetics of mPSCs (i.e., the rise and decay time) nor the amplitudes of the recorded currents were significantly different among groups (data not shown).

Interestingly, however, the analysis of the frequency of mPSC events revealed that neurons grown in the $\mathrm{A}^{\mathrm{ko} / \mathrm{ko}} \mid \mathrm{N}^{\mathrm{ko} / \mathrm{ko}}$ combination exhibited a strongly reduced mEPSC frequency $(0.06 \pm$ $0.006 \mathrm{~Hz}, n=13$ neurons, $p=0.02)$ compared with control cultures $(0.2 \pm 0.031 \mathrm{~Hz}, n=15$ neurons; Fig. $2 C)$. As observed for mEPSCs, no difference in the kinetics or amplitude of mIPSCs was recorded from neurons grown in the different co-culture combinations of wild-type or knock-out cells (Fig. 2B) after 14 DIV. However, as was the case for mEPSCs we observed that neurons grown in $\mathrm{A}^{\mathrm{ko} / \mathrm{ko}} \mid \mathrm{N}^{\mathrm{ko} / \mathrm{ko}}(0.08 \pm 0.002 \mathrm{~Hz}, n=12$ neurons, $p=0.02)$ and in $\mathrm{A}^{\mathrm{w} / \mathrm{w}} \mid \mathrm{N}^{\mathrm{ko} / \mathrm{ko}}(0.1 \pm 0.005 \mathrm{~Hz}, n=30$ neurons, $p=0.03$ ) cultures displayed significantly decreased values for functional parameters of mIPSCs compared with 

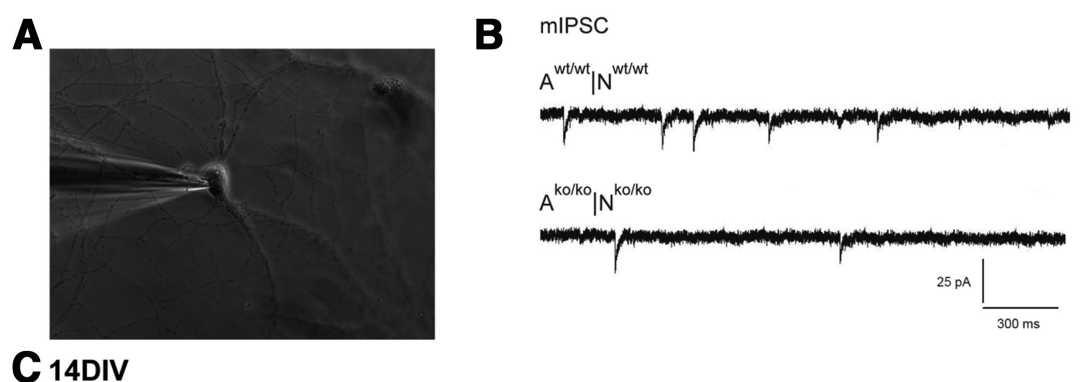

\section{14DIV}
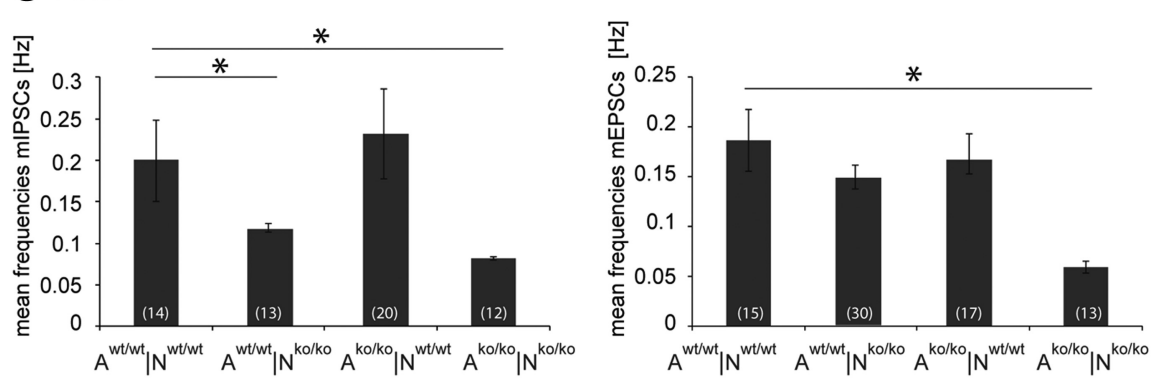

\section{21DIV}
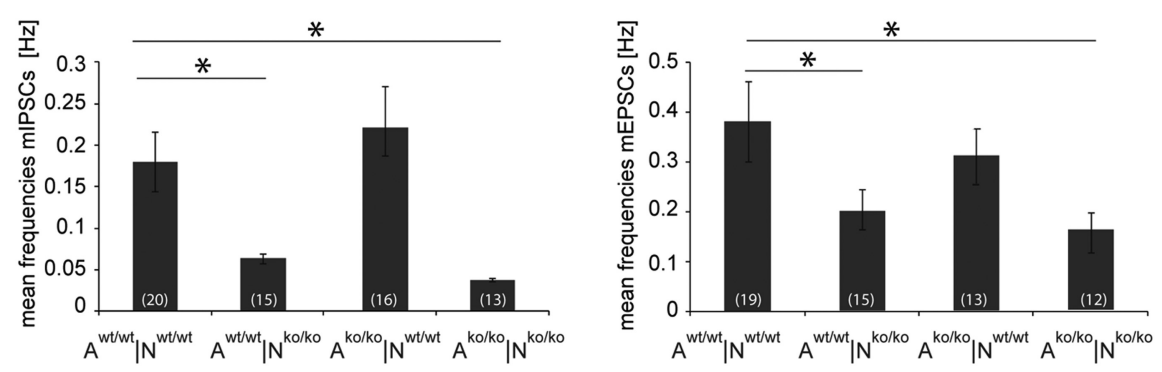

Figure 2. Whole-cell voltage-clamp recordings of mIPSCs and mEPSCs in the four astrocyte-neuron culture combinations after 14 and 21 DIV. $\boldsymbol{A}$, Photomicrograph of a representative primary hippocampal neuron (14 DIV) in whole-cell voltage-clamp recording at $-60 \mathrm{mV}$. $B$, mIPSCs recorded from wild-type $\left(A^{\mathrm{w} / \mathrm{w}} \mid \mathrm{N}^{\mathrm{w} / \mathrm{w}}\right)$ and knock-out $\left(A^{\mathrm{ko} / \mathrm{ko}} \mid \mathrm{N}^{\mathrm{ko} / \mathrm{ko}}\right)$ cell culture combinations. For the pharmacological isolation of mIPSCs, tetrodotoxin $(1 \mu \mathrm{m})$ and DNQX $(10 \mu \mathrm{m})$ were added to the bath solution. $C$, Mean frequencies of mIPSCs and mEPSCs after 14 DIV were significantly decreased in the $A^{\mathrm{w} / \mathrm{w}} \mid \mathrm{N}^{\mathrm{ko} / \mathrm{ko}}$ and $A^{\mathrm{ko} / \mathrm{ko}} \mid \mathrm{N}^{\mathrm{ko} / \mathrm{ko}}$ culture combinations. D, After 21 DIV, mIPSC and mEPSC mean frequencies of the $A^{\mathrm{w} / \mathrm{w} /} \mid N^{\mathrm{ko} / \mathrm{ko}}$ and $A^{\mathrm{ko} / \mathrm{ko}} \mid N^{\mathrm{ko} / \mathrm{ko}}$ combinations showed a significant reduction compared with control cultures. Data are represented as mean $\pm S E M$. and were considered significantly different at $p \leq 0.05$ using ANOVA. The respective $n$ is indicated in brackets.

$\mathrm{A}^{\mathrm{w} / \mathrm{w}} \mid \mathrm{N}^{\mathrm{w} / \mathrm{w}}$ control neurons $(0.2 \pm 0.05 \mathrm{~Hz}, n=14$ neurons; Fig. 2C).

It has been reported that the ECM matures at the end of the second and the beginning of the third week in culture, when brevican and hyaluronan accumulate on neuronal surfaces (Frischknecht et al., 2009). Based on this observation, we exploited the fact that the neurons remained stable for $>21$ DIV in our model, allowing for further electrophysiological recordings. Using the standard whole-cell patch-clamp protocol, we investigated cultures after 3 weeks. Comparable to the results obtained in 14-d-old cultures, mPSC kinetics and amplitude did not differ between groups, but the frequency of mEPSCs was affected: neurons grown in $\mathrm{A}^{\mathrm{ko} / \mathrm{ko}} \mid \mathrm{N}^{\mathrm{ko} / \mathrm{ko}}(0.16 \pm 0.04 \mathrm{~Hz}, n=12$ neurons, $p=$ $0.02)$, but also in the $\mathrm{A}^{\mathrm{w} / \mathrm{w}} \mid \mathrm{N}^{\mathrm{ko} / \mathrm{ko}}$ combination $(0.2 \pm 0.04, n=$ 15 neurons, $p=0.02$ ), showed reduced mEPSC frequencies compared with $\mathrm{A}^{\mathrm{w} / \mathrm{w}} \mid \mathrm{N}^{\mathrm{w} / \mathrm{w}}$ control cultures $(0.4 \pm 0.08 \mathrm{~Hz}, n=19$ neurons; Fig. 2D). Again, mIPSC frequency of neurons recorded in the $\mathrm{A}^{\mathrm{w} / \mathrm{w}} \mid \mathrm{N}^{\mathrm{ko} / \mathrm{ko}}(0.06 \pm 0.006 \mathrm{~Hz}, n=15$ neurons, $p=0.01)$ and $\mathrm{A}^{\mathrm{ko} / \mathrm{ko}} \mid \mathrm{N}^{\mathrm{ko} / \mathrm{ko}}$ combinations $(0.04 \pm 0.002 \mathrm{~Hz}, n=13$ neurons, $p=0.01)$ were significantly reduced compared with control cultures $(0.18 \pm 0.04 \mathrm{~Hz}, n=20$ neurons; Fig. $2 D)$.
Our data clearly demonstrate that the frequency of mPSCs is a functional parameter affected in neurons obtained from animals missing four distinct ECM components, whereas other electrophysiological parameters were not affected. The frequency of mPSCs represents a presynaptic parameter and, therefore, our results differ from the phenotype observed after treatment of the neurons with hyaluronidase, which affected postsynaptic parameters such as the mobility of receptors in the subsynaptic domain (Frischknecht et al., 2009).

Analysis of GAD 65, GAD 67, and vGlut proteins in the neuronal cultures by Western blotting

The detection of EPSC or IPSC currents measured by whole-cell patch-clamp recordings clearly suggested the formation of excitatory and inhibitory synapses. Therefore, the expression levels of key components of inhibitory and excitatory neurotransmission were determined in the different co-culture situations. To verify whether a proportional shift of inhibitory and excitatory neuronal subpopulations occurs, the expression of the two GAD isoforms, 65 and 67 (GAD 65/ 67 ), and of vGlut was determined after 14 and 21 DIV in the four different neuronastrocyte combinations using Western blotting (Fig. 3). Both the GAD 65/67 and the vGlut proteins were clearly detectable in the indirect co-cultures in all combinations, in agreement with the presence of excitatory and inhibitory currents under these conditions. The GAD 65/67 expression relative to $\beta$ III-tubulin seemed to augment in all four combinations from 14 to $21 \mathrm{DIV}$, reflecting the vitality and proper development of the neuronal network (Fig. $3 A, B$ ). In particular co-culture situations, these emerging differences appeared to be statistically relevant (ANOVA $p \leq 0.05$ ). Therefore, significantly enhanced GAD 65/67 expression was detectable in the mutant compared with wild-type neurons after 14 DIV independently of the genotype of the astrocyte layer added (Fig. $3 B$ ). Whether this difference reflects a shift in the balance of inhibitory versus excitatory neurons in the mutant neuronal monolayers remains a topic for future studies. So far, we have not been able to distinguish these subpopulations efficiently in our cultures using available markers. To evaluate the presence of excitatory neurons, the expression of the vesicular glutamate transporter vGlut was assessed in our model. In all four cultured neuron-astrocyte combinations (Fig. 3C), a strong vGlut expression was demonstrable after both 14 and 21 DIV (Fig. 3D) and no striking differences of expression were detected.

\section{Regulation of synapse density by ECM constituents in cell insert cultures}

To investigate whether the electrophysiological phenotype of significantly decreased mIPSC and mEPSC frequencies in the 
knock-out neurons (Fig. 2) was paralleled by a reduced expression of synaptic puncta, we performed immunocytochemical stainings, followed by a semiautomatic readout of synaptic puncta expression (Ippolito and Eroglu, 2010). To this end, immunodetection of Bassoon and PSD95 as presynaptic and postsynaptic markers, respectively, was performed in the four different combinations of mutant and wild-type neurons after 14 and 21 DIV (Fig. 4). Inhibitory synapses could be revealed using the marker gephyrin (data not shown). Primary hippocampal neurons grown in indirect co-culture with astrocytes developed synaptic puncta and built structural synapses after $7 \mathrm{~d}$ in culture, analogous to the situation in rat. The immunological detection revealed a punctate staining pattern of the synaptic proteins (Fig. 4A, $C$ and higher magnification). In addition to the detection of Bassoon-positive and PSD95-positive puncta, we also observed overlapping dots indicating the colocalization of both proteins, which is considered a criterion for the formation of structurally intact synapses (Pyka et al., 2011a). The numbers of presynaptic, postsynaptic, and overlapping puncta were determined after 14 and $21 \mathrm{~d}$; Table 2 shows the results of one representative experiment. Because the overall activity of synapse formation varied between independent experiments, the relative percent increase or percent decrease of synapse numbers was calculated for comparison (Pyka et al., 2011a).

When wild-type or mutant neurons were cultivated in the presence of ECM-deficient astrocytes, an elevated formation of synaptic puncta compared with the control situation $\left(\mathrm{A}^{\mathrm{w} / \mathrm{w}}\right.$ $\mathrm{N}^{\mathrm{w} / \mathrm{w}}$ ) after 14 DIV (Fig. 4B, Table 2) was noted. This observation may reflect a reduced level of inhibitory CSPGs that are released by astrocytes (Kwok et al., 2011), because we reported previously that the selective removal of this category of ECM components by chondroitinase $\mathrm{ABC}$ treatment promotes synapse formation (Pyka et al., 2011b).

An analogous analysis was performed with more mature cultures after 21 DIV (Fig. 4C, Table 2). Generally, the overall expression of synaptic puncta increased with time in all four permutations of wild-type with knock-out cells, reflecting a progressive and adequate maturation of the cultures (Table 2). In contrast to the situation recorded after 2 weeks, however, we found a statistically significant and robust relative percent decrease of the expression of synaptic puncta according to the presynaptic or postsynaptic and overlapping markers compared with the wild-type situation $\left(\mathrm{A}^{\mathrm{w} / \mathrm{w}} \mid \mathrm{N}^{\mathrm{w} / \mathrm{w}}\right)$ in the three combinations in which either one or both cell populations was of mutant origin (see Fig. 4C, Table 2). Remarkably, it was not possible to rescue the relative deficit of synapse formation by co-cultivating the knock-out neurons with wild-type astrocytes or vice-versa.

In the $\mathrm{A}^{\mathrm{w} / \mathrm{w}}\left|\mathrm{N}^{\mathrm{ko} / \mathrm{ko}}, \mathrm{A}^{\mathrm{ko} / \mathrm{ko}}\right| \mathrm{N}^{\mathrm{w} / \mathrm{w}}$, and $\mathrm{A}^{\mathrm{ko} / \mathrm{ko}} \mid \mathrm{N}^{\mathrm{ko} / \mathrm{ko}}$ combination, the number of synaptic puncta appeared significantly reduced (Fig. $4 D$, Table 2). To exclude that the apparent changes reflected modifications of size, the apparent puncta diameters were determined on the images and did not significantly differ between conditions $\left(\mathrm{A}^{\mathrm{w} / \mathrm{w}} \mid \mathrm{N}^{\mathrm{w} / \mathrm{w}}: 0.3 \pm 0.01 \mu \mathrm{m}, n=331 ; \mathrm{A}^{\mathrm{ko} /}\right.$ $\left.\mathrm{ko} \mid \mathrm{N}^{\mathrm{ko} / \mathrm{ko}}: 0.27 \pm 0.01 \mu \mathrm{m}, n=229\right)$. Because a decrease of synapses could mirror a diminished population, cell densities were monitored and found equivalent in the different situations ( $\mathrm{Ta}-$ ble 3). Consistent with this observation, the viability of the neurons was comparable, reflected by a fraction of $\sim 6 \%$ caspase- 3 positive cells in each of the different culture combinations at 21 DIV (data not shown).

In summary, these observations indicated that the ECM of both neuronal and glial origin is required for synapse formation and stabilization over cultivation periods of 3 weeks.

\section{PNN formation in primary hippocampal neurons lacking four matrix components}

A subpopulation of neurons is known to recruit a defined set of matrix molecules to form PNNs (Celio et al., 1998). PNNs that accumulate around maturing neurons represent a specialized form of the ECM. The restricted matrix expression in the quadruple knock-out mouse under study might affect the PNN formation and thereby contribute secondarily to the observed changes of synaptic physiology and morphology. For this reason, the PNN formation and maintenance was investigated in the in vitro culture model.

Initial formation of PNNs around a small subpopulation of neurons in the indirect neuron-astrocyte co-culture was recognized around 10 DIV by WFA staining (data not shown). The lattice-like matrix spanned the neuronal cell body and apical dendrites at an increasing extent and complexity over time in culture. The formation of PNNs in the four different combinations after 14 and 21 DIV (Fig. $5 A, B$ ) was quantified using WFA labeling. 
A
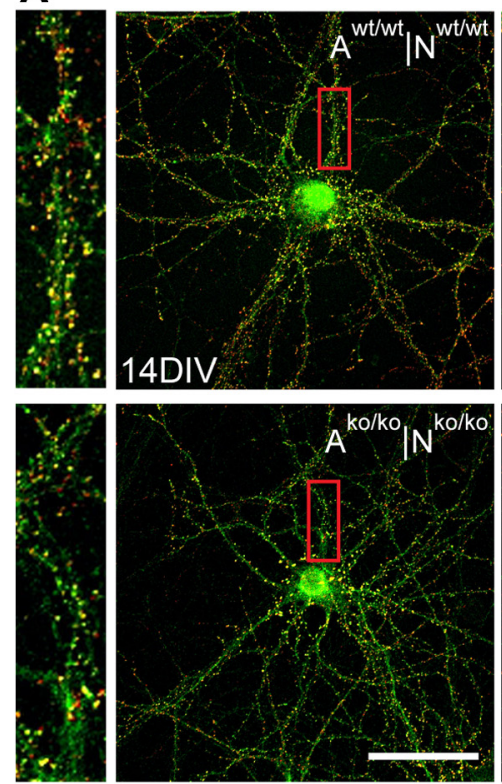

C
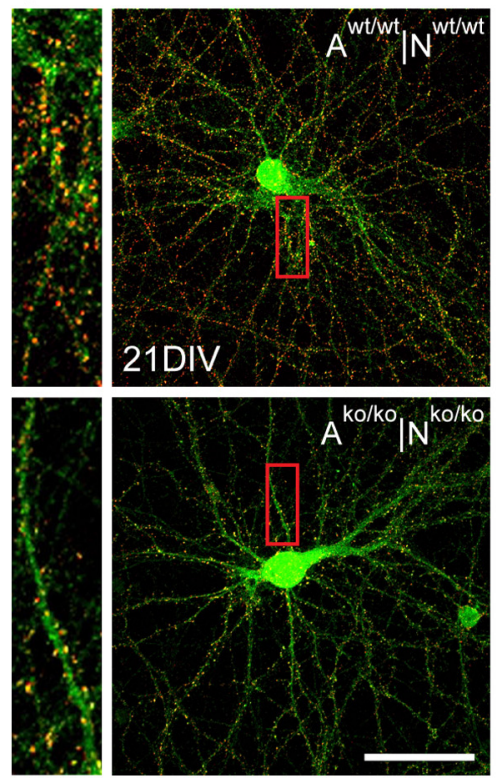
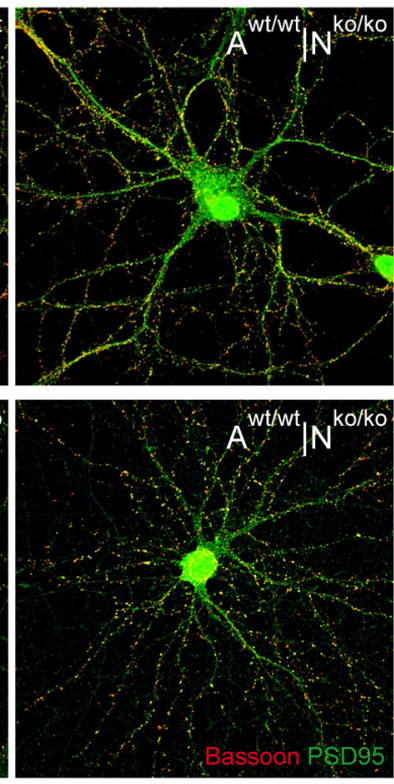
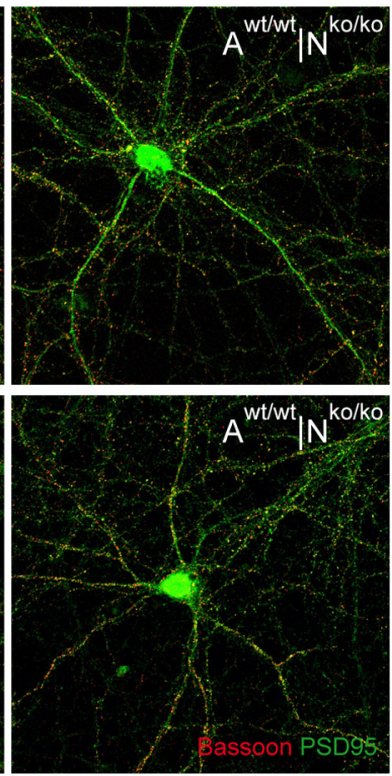

B

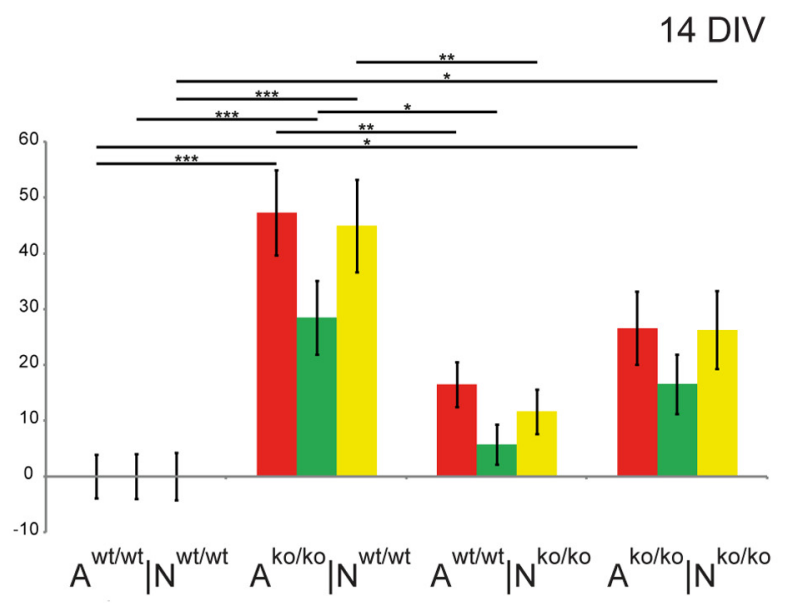

Bassoon

- PSD95

Colocalisation

D

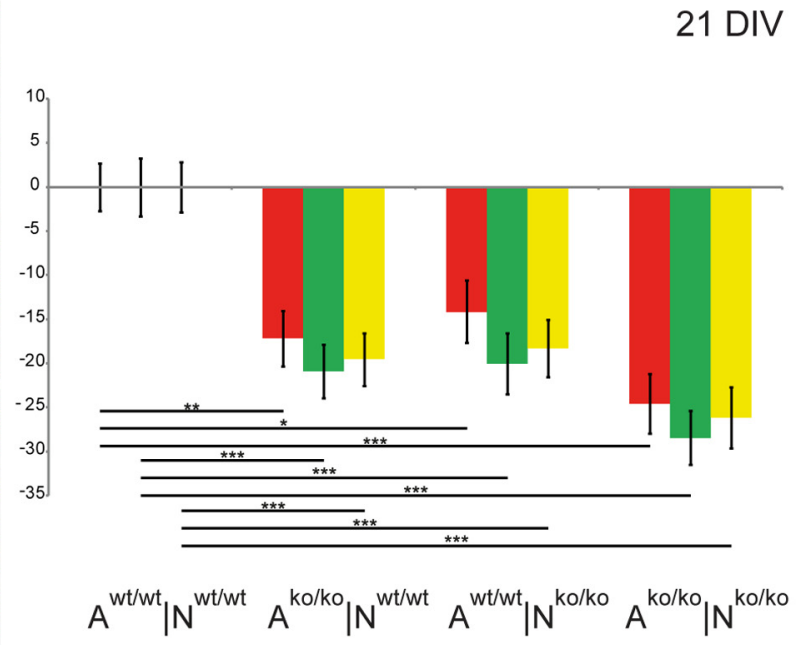

Figure 4. Synaptic puncta expression in primary hippocampal neuron-astrocyte co-cultures of different genotype combinations. Immunocytochemical stainings of primary hippocampal neurons were performed with antibodies against Bassoon and PSD 95. Neurons were grown for 14 DIV ( $\boldsymbol{A})$ and 21 DIV ( $\boldsymbol{C}$ ) in the four different neuron-astrocyte combinations as indicated (A indicates astrocyte genotype; $\mathrm{N}$, neuron genotype). Areas of higher magnifications are indicated in the red boxes and are shown in adjacent images. Scale bar, $20 \mu \mathrm{m}$. Quantification of the punctate staining (red puncta: bassoon; green puncta: PSD 95; yellow puncta: colocalization of both) after 14 DIV (B) and 21 DIV (D). Data represent mean values \pm SEM of percent decrease and percent increase compared with the control situation $\left(A^{\mathrm{w} / \mathrm{w}} \mid \mathrm{N}^{\mathrm{w} / \mathrm{w}}\right)$. For the bar graphs, 40 individual neurons were assessed per combination: 160 neurons $(n)$ per given time point and 3 independent experiments $(N)$ were analyzed $(N=3, n=960)$. Because three categories of puncta were measured and the percent increment was calculated for each individual puncta number, the graphs are based on 2880 calculated percent-values. Data were considered significantly different at $p \leq 0.05$ using ANOVA and the Scheffe post hoc test. The significance levels are indicated as follows: ${ }^{*} p \leq 0.05,{ }^{* *} p \leq 0.01,{ }^{* * *} p \leq$ 0.001 .

Aggrecan, a further member of the lectican family of CSPGs, is an important constituent of PNNs (Morawski et al., 2012). Therefore, we tested polyclonal anti-aggrecan antibodies that clearly showed PNNs in chondroitinase-ABC-treated mouse cortex sections, but these were not suited to stain cultures because the protein core seemed less accessible (data not shown). Conversely, chondroitinase $\mathrm{ABC}$ treatment of the co-cultures removes ECM structures altogether (Pyka et al., 2011b) and therefore does not represent an adequate procedure with which to study PNNs in vitro. Because the expression of aggrecan- and
WFA-binding sites appeared congruent and paralleled each other in a study describing an aggrecan mutant (Giamanco et al., 2010), we focused on WFA to identify PNNs in our system.

In the $\mathrm{A}^{\mathrm{w} / \mathrm{w}} \mid \mathrm{N}^{\mathrm{w} / \mathrm{w}}$ combination, a bright WFA fluorescent signal appeared around $12 \pm 1 \%$ of $\beta$ III-tubulin-positive neurons after 14 DIV (Fig. $5 A, C$ ) and this fraction was maintained in vitro (21 DIV: $11 \pm 1 \%$ of neurons). Despite the partial lack of matrix in the glia cell compartment, we observed that $10 \pm 2 \%$ of $\beta$ IIItubulin-positive neurons were surrounded by PNNs after 14 and 21 DIV (Fig. $5 C$ ) in the $\mathrm{A}^{\mathrm{ko} / \mathrm{ko}} \mid \mathrm{N}^{\mathrm{w} / \mathrm{w}}$ culture. This indicates that 
Table 2. Number of synaptic puncta per neuron in the four different co-culture combinations

\begin{tabular}{|c|c|c|c|c|c|c|}
\hline & \multicolumn{3}{|l|}{14 DIV } & \multicolumn{3}{|l|}{21 DIV } \\
\hline & Bassoon & PSD95 & Colocalized & Bassoon & PSD95 & Colocalized \\
\hline$A^{w t / w t} / N^{w t / w t}$ & $362 \pm 28$ & $517 \pm 43$ & $275 \pm 25$ & $1634 \pm 79$ & $1918 \pm 99$ & $1501 \pm 73$ \\
\hline $\mathrm{A}^{\mathrm{ko} / \mathrm{ko}} \mid \mathrm{N}^{\mathrm{wt} / \mathrm{wt}}$ & $714 \pm 49^{* * *}$ & $832 \pm 78^{* * *}$ & $569 \pm 44^{* * *}$ & $1225 \pm 83^{* *}$ & $1419 \pm 94^{* *}$ & $1121 \pm 76^{* *}$ \\
\hline$A^{\text {wt } / w t} \mid N^{\text {ko } / k o}$ & $511 \pm 24$ & $619 \pm 32$ & $378 \pm 19$ & $1222 \pm 83^{* *}$ & $1357 \pm 102^{* * *}$ & $1093 \pm 75^{* * *}$ \\
\hline $\mathrm{A}^{\mathrm{ko} / \mathrm{ko}} \mid \mathrm{N}^{\mathrm{ko} / \mathrm{ko}}$ & $637 \pm 52^{* * *}$ & $787 \pm 58^{*}$ & $510 \pm 42^{*}$ & $853 \pm 51^{* * *}$ & $1105 \pm 66^{* * *}$ & $803 \pm 51^{* * *}$ \\
\hline
\end{tabular}

The expression of Bassoon (presynaptic) and PSD95 (postsynaptic) puncta in neuronal cultures was analyzed using the puncta analyzer plug-in for ImageJ. The values indicate the average number of puncta per neuron that were recorded for the presynaptic (Bassoon), the postsynaptic (PSD95), and the colocalized markers (overlap of Bassoon and PSD95) in a representative experiment. Values are given as the average number of puncta \pm SEM. For each condition, 40 neurons were counted, which is $n=160$ for each time point and thus $n=320$ for 14 DIV and 21 DIV. Differences compared with the $A$ wt $/ w t / N$ wt $/$ wt control situation for a given time point were assessed by ANOVA and significance levels are indicated by asterisks. ${ }^{*} p \leq 0.05,{ }^{* *} p<0.01,{ }^{* * *} p<0.001$. Overall, 320 individual neurons yielding 960 puncta number counts were evaluated for this table. For comparison of independent experiments, the percent increase or decrease increments were calculated and are presented as a bar graph in Figure $4 B, D$.

Table 3. Cell densities in the different culture combinations

\begin{tabular}{lllll}
\hline & $A^{\text {wt } / \mathrm{wt}} \mid \mathrm{N}^{\mathrm{wt} / \mathrm{wt}}$ & $\mathrm{A}^{\mathrm{ko} / \mathrm{ko}} \mid \mathrm{N}^{\mathrm{wt} / \mathrm{wt}}$ & $\mathrm{A}^{\mathrm{wt} / \mathrm{wt}} \mid \mathrm{N}^{\mathrm{ko} / \mathrm{ko}}$ & $\mathrm{A}^{\mathrm{ko} / \mathrm{ko}} \mid \mathrm{N}^{\mathrm{ko} / \mathrm{ko}}$ \\
\hline $14 \mathrm{DIV}$ & $77 \pm 3$ & $78 \pm 3$ & $80 \pm 3$ & $79 \pm 4$ \\
21 DIV & $76 \pm 3$ & $78 \pm 3$ & $76 \pm 2$ & $78 \pm 2$ \\
\hline
\end{tabular}

Cells visible in five visual fields of the neuronal monolayer chosen at random were counted. At least three independent experiments were monitored per culture combination and time point. Average numbers were calculated and rounded to integers. There were no notable differences in cell culture density or survival between the different culture combinations.

neurons were still capable of proper net formation despite the lack of four matrix molecules in the astrocyte compartment. The immunodetection of PNNs after 14 DIV revealed a remarkably different picture in the knock-out neurons: only $5 \pm 1 \%$ of $\beta$ IIItubulin-positive neurons were decorated by a WFA-positive staining pattern in the $\mathrm{A}^{\mathrm{ko} / \mathrm{ko}} \mid \mathrm{N}^{\mathrm{ko} / \mathrm{ko}}$ combination. Remarkably, this outcome could not be rescued by the addition of wild-type astrocytes (Fig. 5C). After 21 DIV, the fraction of PNN-wearing neurons further decreased significantly to $2 \pm 0 \%$ in the $\mathrm{A}^{\mathrm{ko} / \mathrm{ko}} \mid \mathrm{N}^{\mathrm{ko} / \mathrm{ko}}$ combination and to $3 \pm 0 \%$ in the $\mathrm{A}^{\mathrm{w} / \mathrm{w}} \mid \mathrm{N}^{\mathrm{ko} / \mathrm{ko}}$ combination compared with the $A^{\mathrm{w} / \mathrm{w}} \mid \mathrm{N}^{\mathrm{w} / \mathrm{w}}$ combination (Fig. 5C).

Beyond the overall decreased percentage of neurons that carried PNNs, a significant reduction of net size could also be noted in knock-out neurons (Fig. $5 A, B, D$ ). Using pixel quantification of the WFA staining, an increase of PNN size over time could be clearly documented in the $\mathrm{A}^{\mathrm{w} / \mathrm{w}} \mid \mathrm{N}^{\mathrm{w} / \mathrm{w}}$ control, and the ECM network accumulated over a larger surface with increasing time in culture $\left(\mathrm{A}^{\mathrm{w} / \mathrm{w}} \mid \mathrm{N}^{\mathrm{w} / \mathrm{w}} 14\right.$ DIV: 10,785 \pm 1332 pixels; 21 DIV: $21,117 \pm 7558$ pixels). In contrast, the co-culture combination depleted of the four matrix molecules $\left(\mathrm{A}^{\mathrm{ko} / \mathrm{ko}} \mid \mathrm{N}^{\mathrm{ko} / \mathrm{ko}}\right)$ resulted in a significantly decreased PNN size that diminished further after 21 DIV (Fig. 5D). Because astrocytes express a wide range of matrix genes, the question we addressed was whether wild-type astrocytes might compensate for the thwarted PNN formation. The addition of wild-type astrocytes to the knock-out neurons $\left(\mathrm{A}^{\mathrm{w} / \mathrm{w}} \mid \mathrm{N}^{\mathrm{ko} / \mathrm{ko}}\right)$ also resulted in a significantly decreased PNN size after $14 \operatorname{DIV}(2834 \pm 435$ pixels, $p=0.01)$ and after 21 DIV (765 \pm 435 pixels, $p=0.001)$. Conversely, wild-type neurons co-cultured with knock-out astrocytes displayed significantly larger PNN sizes than those generated by the knock-out neurons after 14 DIV (8567 \pm 1822 pixels $)$ and 21 DIV (10,281 \pm 3691 pixels; $p<0.05$; Fig. $5 D$ ). This suggests that the neuronal genotype was the decisive parameter for PNN formation in our model.

In summary, the knock-out of Tnc, Tnr, brevican, and neurocan resulted in strongly compromised $\mathrm{PNN}$-formation around primary hippocampal neurons, which could not be rescued by the neighboring wild-type astrocytes (Fig. 5D).

\section{Synapse formation on PNN-wearing neurons}

The results reported above suggested that primary hippocampal neurons lacking four matrix components are characterized by a failure of PNN formation and maintenance. Furthermore, evidence was provided that the number of synapses is modified in the quadruple matrix mutation. For these reasons, we decided to investigate synapse formation focusing on the subpopulation of PNN-coated neurons. Triple immunocytochemical stainings were performed using WFA and antibodies against the presynaptic protein Bassoon and the postsynaptic constituent PSD 95 (Fig. 6). Using this approach, the punctuate patterns of synaptic proteins were located in discrete areas and flanked by WFA-positive matrix material in their immediate vicinity. Interestingly, the enrichment of synaptic puncta was correlated directly with the gaps in the lattice-like WFA staining (Fig. 6A,B). This was confirmed by analysis of the color profile showing that the corresponding fluorescent spectra on a representative neurite revealed a clear reciprocal complementary arrangement (Fig. 6B). Both Bassoon and PSD 95 appeared clearly framed by the PNNs.

To investigate modifications in the expression of synaptic puncta with reference to the PNN-coated subpopulation of neurons, the colocalization of both presynaptic and postsynaptic proteins in local puncta was quantified via semiautomatic readout using ImageJ (Ippolito and Eroglu, 2010; Pyka et al., 2011a; Fig. 6). In contrast to the results obtained with the randomly picked neurons, a significant reduction of synaptic puncta expression after 14 DIV and 21 DIV was observed on knock-out neurons expressing residual PNNs (Fig. 6). The mean percentage of the decrease in synaptic puncta expression after 14 DIV was highly significant and attained up to $-70 \%$ for the markers Bassoon and PSD 95, as well as for the colocalization of both puncta when knock-out neurons were combined with knock-out astrocytes (Fig. $6 E, \mathrm{~A}^{\mathrm{ko} / \mathrm{ko}} \mid \mathrm{N}^{\mathrm{ko} / \mathrm{ko}}$ ). This effect could not be rescued by the co-cultivation with wild-type astrocytes $\left(\mathrm{A}^{\mathrm{w} / \mathrm{w}} \mid \mathrm{N}^{\mathrm{ko} / \mathrm{ko}}\right)$. Cocultures in which matrix-deficient astrocytes were used were also examined. When combined with wild-type neurons, the absence of the four matrix molecules did not result in a significantly decreased formation of synaptic puncta (Fig. 6E).

After 3 weeks in culture, similar effects were observed in that the absence of the four ECM molecules resulted in reduced synaptic puncta expression in both the $\mathrm{A}^{\mathrm{w} / \mathrm{w}} \mid \mathrm{N}^{\mathrm{ko} / \mathrm{ko}}$ and $\mathrm{A}^{\mathrm{ko} / \mathrm{ko}} \mid \mathrm{N}^{\mathrm{ko} / \mathrm{ko}}$ combinations, although the effect seemed slightly less pronounced than after 14 DIV (Fig. 6F). In the rescue experiment in which wildtype astrocytes were added to knock-out neurons $\left(\mathrm{A}^{\mathrm{w} / \mathrm{w}} \mid \mathrm{N}^{\mathrm{ko} / \mathrm{ko}}\right)$, no correction of this deficit could be obtained. Again, the use of matrix-deficient astrocytes did not mitigate synapse formation between wild-type neurons.

Summarizing these results, the synapse formation in the PNN-wearing neurons was severely affected by the matrix knockout. This phenotype could not be rescued by wild-type astrocytes, whereas the co-culture with a mutant astrocytic compartment did not significantly affect the expression of synaptic puncta. This 
A
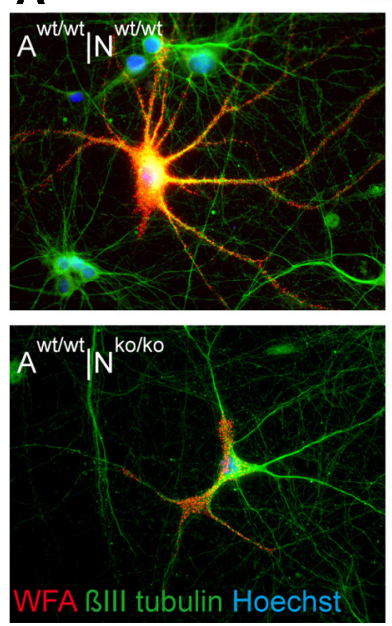

C

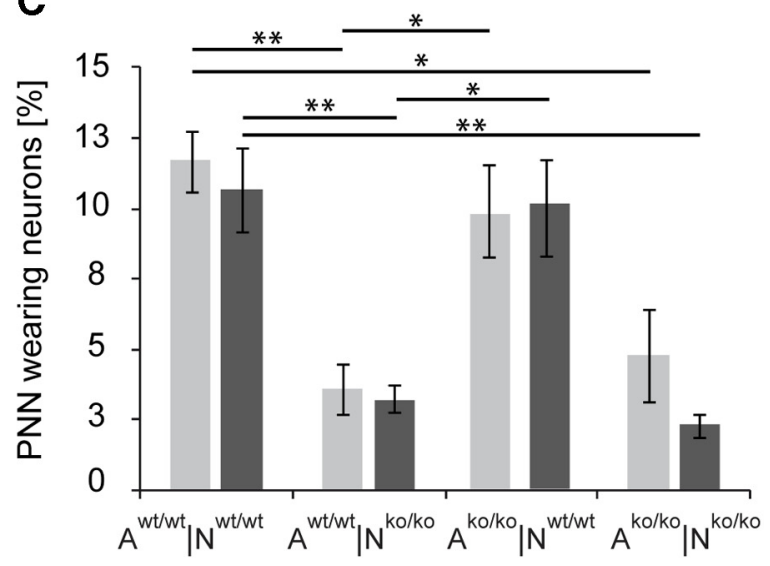

Genotype astrocytes (A) and neurons (N)
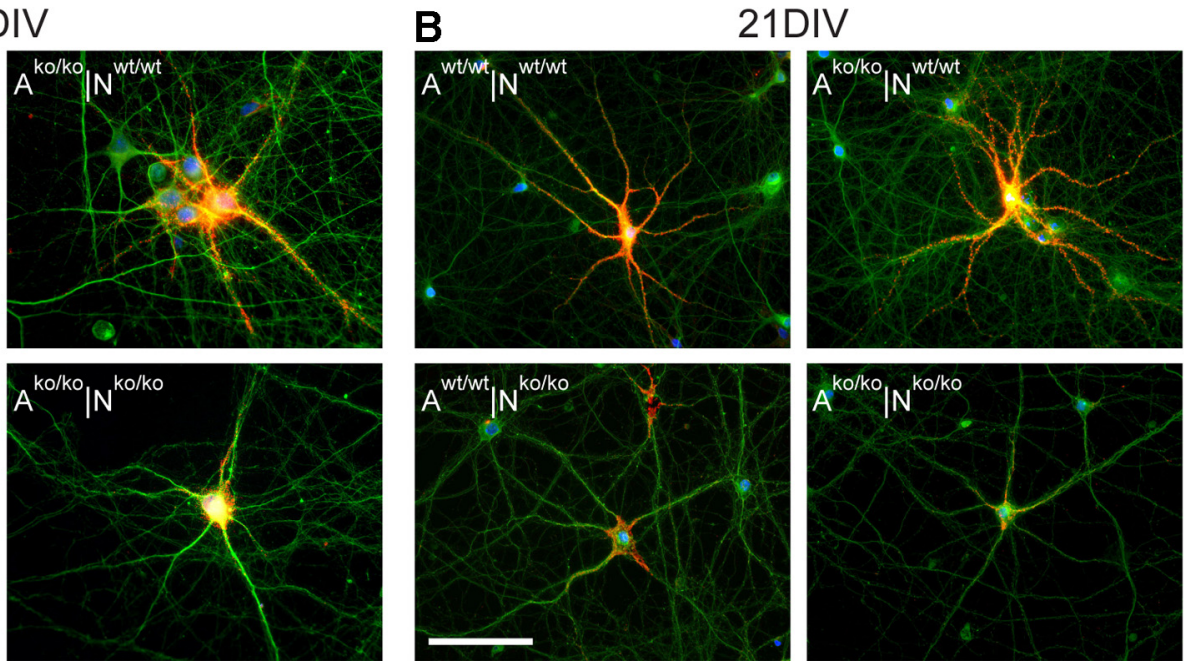

D

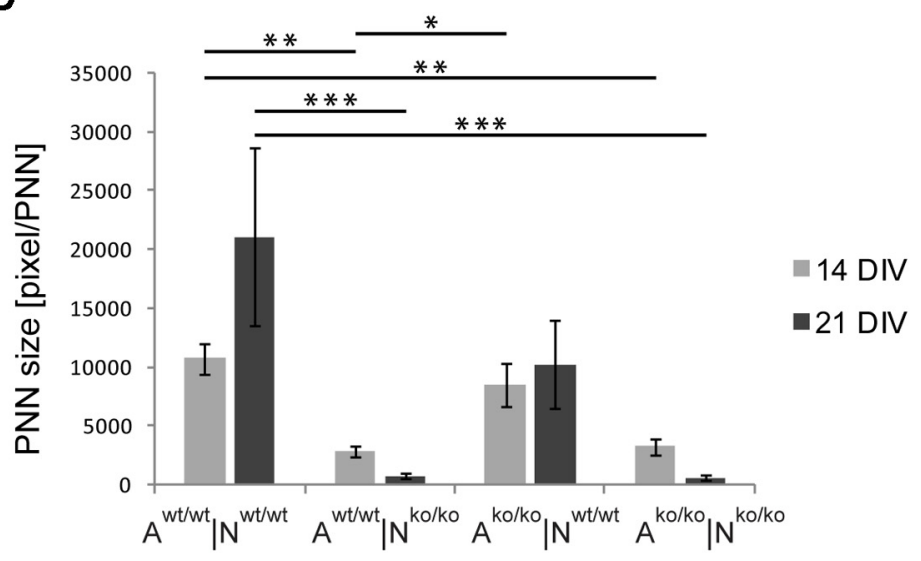

Genotype astrocytes (A) and neurons (N)

Figure 5. PNN formation in vitro. Detection of PNNs accumulated around $\beta$ III-tubulin-positive neurons after 14 DIV $(\boldsymbol{A})$ and 21 DIV $(\boldsymbol{B})$ via WFA binding. Primary hippocampal neurons from different genotypes were co-cultured with respective astrocytes as indicated (A indicates the astrocyte genotype; $\mathrm{N}$, the neuron genotype). $\mathrm{Scale}$ bar, $50 \mu \mathrm{m}$. The percentage of PNN-bearing neurons was quantified in three independent experiments and is shown in $\boldsymbol{C}(N=3, n=1200)$. The size of the nets was quantified via respective pixel counting and is shown in $\boldsymbol{D}(N=3)$. Data were considered significantly different at $p \leq 0.05$ using ANOVA and the Scheffe post hoc test. The significance levels are indicated as follows: ${ }^{*} p \leq 0.05,{ }^{* *} p \leq 0.01,{ }^{* * *} p \leq 0.001$. Error bars indicate \pm SEM. The $A^{\mathrm{w} / \mathrm{w}} \mid \mathrm{N}^{\mathrm{ko} / \mathrm{ko}}$ and $\mathrm{A}^{\mathrm{ko} / \mathrm{ko}} \mid \mathrm{N}^{\mathrm{ko} / \mathrm{ko}}$ combinations were indistinguishable in statistical analysis. Not all horizontal bars are included for the sake of clarity of the graph.

Table 4. Whole-cell patch-clamp analysis of PNN-wearing neurons

\begin{tabular}{|c|c|c|c|c|c|c|}
\hline & $\begin{array}{l}\mathrm{A}^{\mathrm{wt} / \mathrm{wt}} \mid \mathrm{N}^{\mathrm{wt} / \mathrm{wt}} \\
\text { Control } \\
(21 \mathrm{DIV}, n=20) \\
\mathrm{mIPSCS}\end{array}$ & $\begin{array}{l}\mathrm{A}^{\mathrm{wt} / \mathrm{wt}} \mid \mathrm{N}^{\mathrm{wt} / \mathrm{wt}} \\
\text { PNN-positive } \\
\text { (21 DIV, } n=10 \text { ) } \\
\text { mIPSCs }\end{array}$ & $\begin{array}{l}\text { A }^{\mathrm{ko} / \mathrm{ko}} \mid \mathrm{N}^{\mathrm{ko} / \mathrm{ko}} \\
\text { PNN-positive } \\
\text { (21 DIV, } n=6 \text { ) } \\
\text { mIPSCs }\end{array}$ & $\begin{array}{l}\mathrm{A}^{\mathrm{wt} / \mathrm{wt}} \mid \mathrm{N}^{\mathrm{wt} / \mathrm{wt}} \\
\text { Control } \\
(21 \mathrm{DIV}, n=19) \\
\mathrm{mEPSCs}\end{array}$ & $\begin{array}{l}\mathrm{A}^{\mathrm{wt} / \mathrm{wt}} \mid \mathrm{N}^{\mathrm{wt} / \mathrm{wt}} \\
\text { PNN-positive } \\
\text { (21 DIV, } n=12 \text { ) } \\
\text { mEPSCs }\end{array}$ & $\begin{array}{l}\mathrm{A}^{\mathrm{ko} / \mathrm{ko}} \mid \mathrm{N}^{\mathrm{ko} / \mathrm{ko}} \\
\mathrm{PNN}-\text { positive } \\
\text { (21 DIV, } n=8 \text { ) } \\
\mathrm{mEPSCS}\end{array}$ \\
\hline Amplitude (pA) & $45.4 \pm 2.2$ & $51.3 \pm 6.1$ & $48.6 \pm 6.4$ & $32.2 \pm 2.1$ & $39.4 \pm 5.6$ & $36.4 \pm 34.4$ \\
\hline Charge (Cb) & $143.1 \pm 18.2$ & $147.4 \pm 20.1$ & $152.3 \pm 19.2$ & $133.5 \pm 15.2$ & $151.3 \pm 20.4$ & $138.6 \pm 18.2$ \\
\hline Rise time (ms) & $3.75 \pm 0.4$ & $4.6 \pm 1.1$ & $5.1 \pm 1.6$ & $3.4 \pm 0.5$ & $4.4 \pm 1.7$ & $3.0 \pm 0.8$ \\
\hline Decay time (ms) & $4.2 \pm 0.6$ & $6.6 \pm 21.7$ & $6.4 \pm 2.5$ & $4.2 \pm 0.6$ & $6.2 \pm 2.1$ & $4.6 \pm 1.7$ \\
\hline Frequency & $0.2 \pm 0.36$ & $0.3 \pm 0.02$ & $0.1 \pm 0.06^{*}(p=0.02)$ & $0.4 \pm 0.08$ & $0.6 \pm 0.08$ & $0.3 \pm 0.04^{*}(p=0.02)$ \\
\hline
\end{tabular}

Wild-type neurons in culture were identified on the basis of morphology alone (Control) or after staining with fluorescent WFA-lectin in living cultures to identify PNN-wearing cells (PNN-positive) and recorded by whole-cell patch clamping. No significant differences in the parameters amplitude, charge, or rise and decay time of miniature postsynaptic currents were detected. However, the current frequencies of $\mathrm{mIPSCs}$ and $\mathrm{mEPSCs}$ were significantly reduced in PNN-wearing knock-out neurons $\left(\mathrm{A}^{\mathrm{ko} / \mathrm{ko}} \mid \mathrm{N}^{\mathrm{ko} / \mathrm{ko}}\right.$ ) compared with wild-type neurons ( $\left.\mathrm{A}^{\mathrm{wt} / \mathrm{wt}} \mid \mathrm{N}^{\mathrm{wt}} / \mathrm{wt}\right)$. This is analogous to the results obtained when the neurons were not distinguished with regard to the expression of PNNs (Figure 2$)$. The culture combination is indicated in the respective columns; $n=$ number of individual neurons recorded.

suggests that the synapse deficiency in the first line mirrors a neuronal phenotype in the mutant.

To gain insight into potential electrophysiological correlates of this deficit, PNNs were labeled directly with fluorescent WFA lectin in living cultures and the respective cells were subsequently analyzed by whole-cell patch clamping. The recordings did not reveal differences in the parameters analyzed compared with the results of measurements in which the neurons were recorded regardless of the expression of PNNs. In particular, the frequencies of mIPSCs and mEPSCs appeared reduced in PNN-wearing knock-out compared with wild-type neurons (see above; Fig. 2, Table 4).

\section{Discussion}

The ECM of the nervous system has attracted increasing attention since the discovery that it plays a key role in the control of 
A

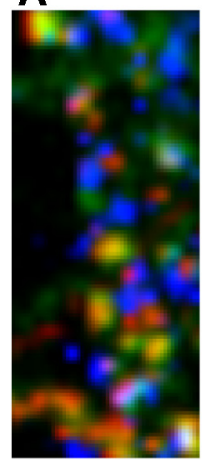

B

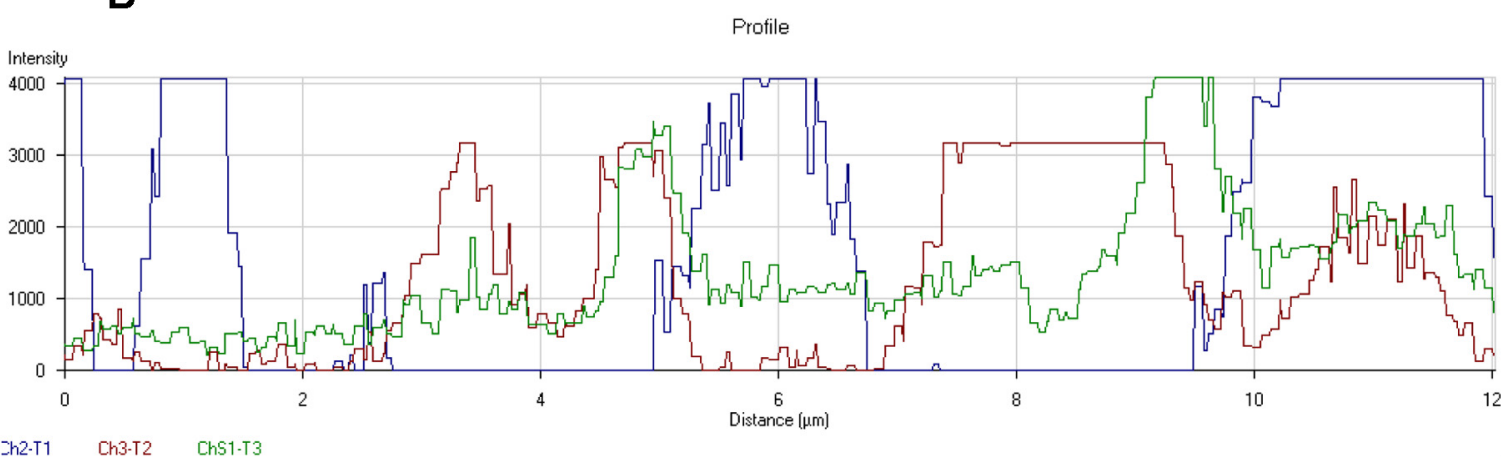

\section{Bassoon PSD95 WFA}

C
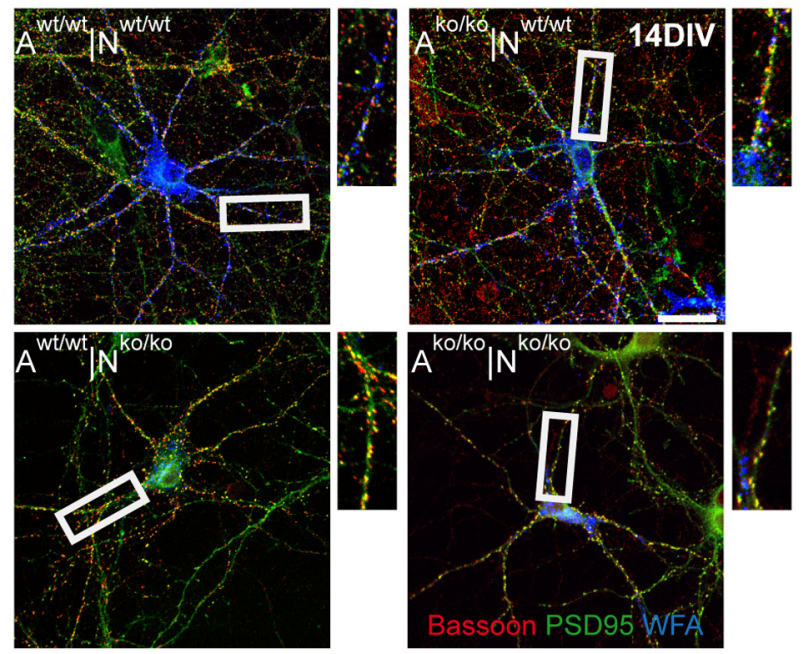

E

14DIV

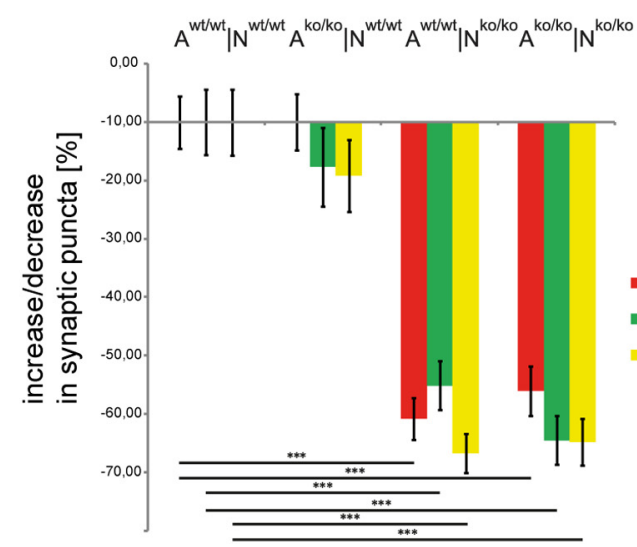

D
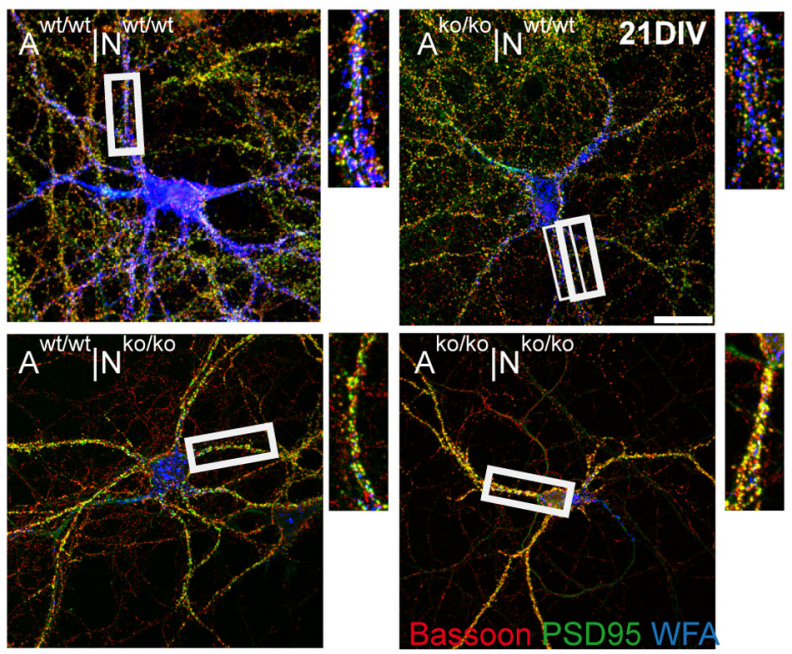

$\mathbf{F}$

21DIV

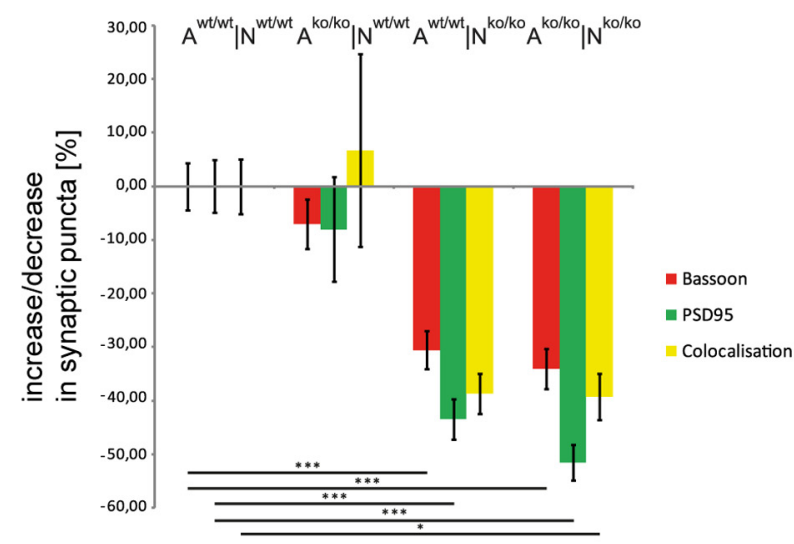

Figure 6. Synapse formation on PNN-coated neurons. Immunocytochemical detection of Bassoon, PSD 95, and PNNs (via WFA binding) in cultures of primary hippocampal neurons is shown. $\boldsymbol{A}$, Triple staining of Bassoon, PSD95, and WFA showing synaptic puncta emerging in the gaps between WFA-positive areas. The correlation is precise and adjacent expression is underlined by the color profile of an exemplary neurite, shown in $\boldsymbol{B}$. C, D, Triple staining of primary hippocampal neurons of different genotypes ( $N$ ) grown in indirect co-culture with respective astrocytes $(\boldsymbol{A})$ after 14 DIV $(\boldsymbol{C})$ and 21 DIV $(\boldsymbol{D})$. Higher magnifications from exemplary neurites are shown in smaller images and the area is outlined in white boxes. Scale bar, $10 \mu \mathrm{m}$. $\boldsymbol{E}$, Quantification of the change in synaptic puncta expression compared with controls ( $\mathrm{A}^{\mathrm{w} / \mathrm{w}} \mid \mathrm{N}^{\mathrm{w} / \mathrm{w}}$ ) after 14 DIV and after 21 DIV $(\boldsymbol{F})$. Data are represented as mean values \pm SEM and were considered significantly different at $p \leq 0.05$ using ANOVA and the Scheffe post hoc test. For the bar graphs, 20 individual PNN-wearing neurons were assessed per combination: 80 neurons $(n)$ per given time point and 3 independent experiments $(N)$ were analyzed $(N=3, n=480)$. The three categories of puncta were measured and the percent increment was calculated for each individual puncta number. Therefore, the graphs are based on 1440 calculated percent-values. Data were considered significantly different at $p \leq 0.05$ using AN0VA and the Scheffe post hoc test. The significance levels are indicated as follows: ${ }^{*} p \leq 0.05,{ }^{* *} p \leq 0.01,{ }^{* * *} p \leq 0.001$. The $A^{\text {w/w }} \mid N^{\text {w/w }}$ and $A^{\text {ko/ko }} \mid N{ }^{w / w}$ combinations were interchangeable in the statistical analysis. Not all horizontal bars are included to enhance the clarity of the graph. 
CNS plasticity (Pizzorusso et al., 2002). We have exploited a mouse mutant that lacks four major ECM molecules, Tnc, Tnr, brevican, and neurocan (Rauch et al., 2005), and we provide evidence that the ECM modulates synaptogenesis and long-term synapse stability. The mutant neurons display reduced frequencies of mEPSCs and mIPSCs. Furthermore, the formation of PNNs was reduced in the mutant cultures and this phenotype could not be rescued by wild-type astrocytes. The synapse formation on mutant PNN-bearing neurons was strongly reduced.

A disappearance of dense PNN structures and the upregulation of two matrix molecules untypical for the CNS (fibulin-1 and fibulin-2) in vivo has been described for the quadruple knock-out mouse (Rauch et al., 2005). Here, we used this mutant as a tool to gain further insights into matrix-dependent plasticity. The combination of both wild-type and mutant neurons, as well as astrocytes in different permutations, revealed the contribution of both cell types to matrix assembly. The hippocampal neuron cultures released Tnc, Tnr, brevican, and neurocan, as deduced from the immunocytochemical detection of these components in co-culture with mutant astrocytes, which is consistent with earlier reports in the literature (Fuss et al., 1993; Zhang et al., 1995; Engel et al., 1996; Ferhat et al., 1996b; Mahler et al., 1996; Lander et al., 1998; Pyka et al., 2011a). However, a potential contribution by a small proportion of neural stem/progenitor cells cannot be excluded in our model. In comparison, astrocytes primarily contributed to the release of brevican and Tnc (Bartsch et al., 1992; Cahoy et al., 2008; Karus et al., 2011). The distinct accumulation of brevican observed around one selected neurite (Fig. 1) confirms earlier reports that highlighted the localization at the axon hillock (John et al., 2006; Hedstrom et al., 2007).

Using whole-cell voltage-clamp recordings, we observed a significantly reduced frequency of mIPSCs and mEPSCs when neurons were matrix deficient. Changes in synaptic connectivity in relation to matrix proteins have been described previously (Bukalo et al., 2001; Evers et al., 2002; Irintchev et al., 2005; Bukalo et al., 2007; Morellini et al., 2010). Therefore, hyaluronan and Tnc are involved in LTP induction, possibly by interacting with L-type voltage-dependent $\mathrm{Ca}^{2+}$ channels (Evers et al., 2002; Kochlamazashvili et al., 2010). It has been shown recently that the lateral mobility of AMPARs is enhanced after enzymatic removal of hyaluronan (Frischknecht et al., 2009), and the ECM has been proposed to function as a diffusion barrier for substances acting within the synaptic cleft (Dityatev et al., 2010b; Gundelfinger et al., 2010). Pyka et al. (2011b) reported a decreased mEPSC amplitude and charge after chondroitinase ABC treatment.

The reduction of frequency of both mEPSCs and mIPSCs recorded upon elimination of the four matrix molecules rather points to a presynaptic effect, which highlights important differences between the two experimental paradigms. The observed changes in the mPSC frequencies can be explained by modifications in the number of functional release sites (Hsia et al., 1998). In fact, both the pool of ready-to-release vesicles and the number of presynaptic inputs affect the frequency of such events.

We monitored the expression levels of GAD65/67 and vGlut to examine the formation of inhibitory and excitatory synapses. After 2 weeks, we found a significantly increased GAD65/67 expression in mutant neurons, which was, however, mitigated after 21 DIV. Interestingly, an earlier study reported an increase of GABAergic neurons in the hippocampus of $\mathrm{Tnr}^{-1-}$ mice (Morellini et al., 2010). Conversely, a lower density of parvalbumin-positive interneurons has been observed in the cortex of Tnc ${ }^{-1-}$ mice (Irintchev et al., 2005). At this point, it cannot be determined whether the elimination of four ECM genes in our model led to an increase in the fraction of $\mathrm{GAD}$-expressing neurons or to a higher expression of GAD in a subpopulation of GABAergic cells. This point merits investigation in future studies, because several reports have suggested that the ECM partakes in activating silent synapses (Ullian et al., 2004; Christopherson et al., 2005). Unlike GAD65/67, the vGlut levels stayed unaltered in the different culture combinations. The persistence of comparable vGLUT expression levels is consistent with the observed constancy of the amplitude of mEPSCs that is controlled by this vGLUT-transporter family (Weston et al., 2011).

An important finding of the present study concerns the involvement of the ECM in synaptic plasticity, as revealed by quantifying the expression of synaptic puncta in our bioassay. It has been demonstrated previously that enzymatic treatment with chondroitinase $\mathrm{ABC}$ resulted in a significantly elevated expression of synaptic structures in rat hippocampal cultures (Pyka et al., 2011b). Consistent with this report, we found an enhanced number of Bassoon- and PSD95-containing puncta in neurons co-cultivated with matrixdeficient astrocytes after 14 DIV. An augmented colocalization of both proteins evolved, indicating the emergence of structural synapses. Therefore, we propose that the reduced number of glialderived matrix molecules resulted in a transiently enhanced synapse formation during the first 2 weeks of development. This increase supports the idea that the matrix plays a repellent and restrictive role, which was demonstrated in several elegant studies in the context of regeneration (Galtrey and Fawcett, 2007; Garcia-Alias and Fawcett, 2012; Wang et al., 2011). To gain insight into the role of the matrix with progressing maturation, the expression of synaptic proteins was investigated after $21 \mathrm{DIV}$. Overall, the number of presynaptic and postsynaptic puncta augmented over time. However, after 3 weeks, the number of synapses was clearly reduced in all combinations in which one or both partner cell populations were of mutant origin compared with the cultivation of exclusively wild-type cells. This shift of synapse numbers can be interpreted as reflecting a dual function of the ECM. During the first 2 weeks, the matrix may control primarily the formation of synaptic sprouts, whereas later on, it may be required for stabilization of synapses (Pyka et al., 2011b). Therefore, the ablation of four dominant matrix components may permit a transient synaptic overshoot and eventually result in a diminished net outcome of stable mature synaptic contacts. In this context in particular chondroitin sulfate proteoglycans that tightly enwrap neurons in PNNs are thought to maintain synapse integrity (Fox and Caterson, 2002; Deepa et al., 2006; Dansie and Ethell, 2011).

PNNs represent characteristic accumulations of matrix molecules around a subpopulation of mature neurons (Celio et al., 1998). In the indirect hippocampal co-cultures, initial PNN formation was observed around 7 DIV, with increasing size emerging over time in vitro. Previous studies have demonstrated that tenascins and the lecticans are expressed in PNNs (Matsui et al., 1998; Carulli et al., 2006; Deepa et al., 2006; Dityatev et al., 2010a). Similarly, an altered PNN formation has been described previously for the Tnr mutant (Brückner et al., 2000) and the quadruple knock-out mouse showed an altered WFA-staining pattern in vivo (Rauch et al., 2005). We found a significantly reduced formation of PNNs around neurons from the quadruple knock-out mouse. This deficit could not be rescued by adding wild-type astrocytes. In contrast, neurondelivered matrix also appeared sufficient to initiate PNN formation in the presence of knock-out astrocytes. The coincidence of PNN formation and the termination of the critical period have led to the hypothesis that PNNs may regulate the plastic potential of the brain (Balmer et al., 2009; Gogolla et al., 2009). Whether the diminished PNN formation and the altered ECM expression also led to enhanced plasticity in our system remains a question for further investigations. The importance of PNNs in synapse formation and stabilization was clearly demonstrated in our analysis, which re- 
vealed that neurons bearing rudimentary PNNs displayed significantly reduced synapse formation after 14 and 21 DIV.

Several recent studies have emphasized the important roles of the neuronal ECM and PNNs for plasticity and regeneration in vivo and in vitro (Carulli et al., 2010; Kwok et al., 2011; Wang et al., 2011; Zhao et al., 2011). However, these studies focused on the impact of the growth-inhibitory GAG chains in a regenerative context. Here, we used a mouse model that lacks four major components of the ECM and document that the ablation of these genes leads to significant changes of synapse development. Therefore, the quadruple mutant represents a valuable model system with which to study neuronal development in general and synaptic plasticity in particular.

\section{References}

Asher RA, Morgenstern DA, Fidler PS, Adcock KH, Oohira A, Braistead JE, Levine JM, Margolis RU, Rogers JH, Fawcett JW (2000) Neurocan is upregulated in injured brain and in cytokine-treated astrocytes. J Neurosci 20:2427-2438. Medline

Balmer TS, Carels VM, Frisch JL, Nick TA (2009) Modulation of perineuronal nets and parvalbumin with developmental song learning. J Neurosci 29:12878-12885. CrossRef Medline

Bartsch S, Bartsch U, Dörries U, Faissner A, Weller A, Ekblom P, Schachner M (1992) Expression of tenascin in the developing and adult cerebellar cortex. J Neurosci 12:736-749. Medline

Beattie EC, Stellwagen D, Morishita W, Bresnahan JC, Ha BK, Von Zastrow M, Beattie MS, Malenka RC (2002) Control of synaptic strength by glial TNFalpha. Science 295:2282-2285. CrossRef Medline

Brakebusch C, Seidenbecher CI, Asztely F, Rauch U, Matthies H, Meyer H, Krug M, Böckers TM, Zhou X, Kreutz MR, Montag D, Gundelfinger ED, Fässler R (2002) Brevican-deficient mice display impaired hippocampal CA1 long-term potentiation but show no obvious deficits in learning and memory. Mol Cell Biol 22:7417-7427. CrossRef Medline

Brückner G, Grosche J, Schmidt S, Härtig W, Margolis RU, Delpech B, Seidenbecher CI, Czaniera R, Schachner M (2000) Postnatal development of perineuronal nets in wild-type mice and in a mutant deficient in tenascin-R. J Comp Neurol 428:616-629. CrossRef Medline

Bukalo O, Schachner M, Dityatev A (2001) Modification of extracellular matrix by enzymatic removal of chondroitin sulfate and by lack of tenascin-R differentially affects several forms of synaptic plasticity in the hippocampus. Neuroscience 104:359-369. CrossRef Medline

Bukalo O, Schachner M, Dityatev A (2007) Hippocampal metaplasticity induced by deficiency in the extracellular matrix glycoprotein tenascin-R. J Neurosci 27:6019-6028. CrossRef Medline

Cahoy JD, Emery B, Kaushal A, Foo LC, Zamanian JL, Christopherson KS, Xing Y, Lubischer JL, Krieg PA, Krupenko SA, Thompson WJ, Barres BA (2008) A transcriptome database for astrocytes, neurons, and oligodendrocytes: a new resource for understanding brain development and function. J Neurosci 28:264-278. CrossRef Medline

Carulli D, Laabs T, Geller HM, Fawcett JW (2005) Chondroitin sulfate proteoglycans in neural development and regeneration. Curr Opin Neurobiol 15:116-120. CrossRef Medline

Carulli D, Rhodes KE, Brown DJ, Bonnert TP, Pollack SJ, Oliver K, Strata P, Fawcett JW (2006) Composition of perineuronal nets in the adult rat cerebellum and the cellular origin of their components. J Comp Neurol 494:559-577. CrossRef Medline

Carulli D, Pizzorusso T, Kwok JC, Putignano E, Poli A, Forostyak S, Andrews MR, Deepa SS, Glant TT, Fawcett JW (2010) Animals lacking link protein have attenuated perineuronal nets and persistent plasticity. Brain 133:2331-2347. CrossRef Medline

Celio MR, Spreafico R, De Biasi S, Vitellaro-Zuccarello L (1998) Perineuronal nets: past and present. Trends Neurosci 21:510-515. CrossRef Medline

Christopherson KS, Ullian EM, Stokes CC, Mullowney CE, Hell JW, Agah A, Lawler J, Mosher DF, Bornstein P, Barres BA (2005) Thrombospondins are astrocyte-secreted proteins that promote CNS synaptogenesis. Cell 120:421-433. CrossRef Medline

Cybulska-Klosowicz A, Zakrzewska R, Pyza E, Kossut M, Schachner M (2004) Reduced plasticity of cortical whisker representation in adult tenascin-C-deficient mice after vibrissectomy. Eur J Neurosci 20:15381544. CrossRef Medline

Czopka T, Hennen E, von Holst A, Faissner A (2009) Novel conserved oli- godendrocyte surface epitope identified by monoclonal antibody 4860 . Cell Tissue Res 338:161-170. CrossRef Medline

Dansie LE, Ethell IM (2011) Casting a net on dendritic spines: The extracellular matrix and its receptors. Dev Neurobiol 71:956-981. CrossRef Medline

Deepa SS, Carulli D, Galtrey C, Rhodes K, Fukuda J, Mikami T, Sugahara K, Fawcett JW (2006) Composition of perineuronal net extracellular matrix in rat brain: a different disaccharide composition for the netassociated proteoglycans. J Biol Chem 281:17789-17800. CrossRef Medline

Di Castro MA, Chuquet J, Liaudet N, Bhaukaurally K, Santello M, Bouvier D, Tiret P, Volterra A (2011) Local $\mathrm{Ca}(2+)$ detection and modulation of synaptic release by astrocytes. Nat Neurosci 14:1276-1284. CrossRef Medline

Dityatev A, Brückner G, Dityateva G, Grosche J, Kleene R, Schachner M (2007) Activity-dependent formation and functions of chondroitin sulfate-rich extracellular matrix of perineuronal nets. Dev Neurobiol 67: 570-588. CrossRef Medline

Dityatev A, Schachner M, Sonderegger P (2010a) The dual role of the extracellular matrix in synaptic plasticity and homeostasis. Nat Rev Neurosci 11:735-746. CrossRef Medline

Dityatev A, Seidenbecher CI, Schachner M (2010b) Compartmentalization from the outside: the extracellular matrix and functional microdomains in the brain. Trends Neurosci 33:503-512. CrossRef Medline

Elmariah SB, Hughes EG, Oh EJ, Balice-Gordon RJ (2004) Neurotrophin signaling among neurons and glia during formation of tripartite synapses. Neuron Glia Biol 1:1-11. Medline

Engel M, Maurel P, Margolis RU, Margolis RK (1996) Chondroitin sulfate proteoglycans in the developing central nervous system. I. cellular sites of synthesis of neurocan and phosphacan. J Comp Neurol 366:34-43. Medline

Evers MR, Salmen B, Bukalo O, Rollenhagen A, Bösl MR, Morellini F, Bartsch U, Dityatev A, Schachner M (2002) Impairment of L-type $\mathrm{Ca}^{2+}$ channel-dependent forms of hippocampal synaptic plasticity in mice deficient in the extracellular matrix glycoprotein tenascin-C. J Neurosci 22:7177-7194. Medline

Faissner A, Kruse J (1990) J1/tenascin is a repulsive substrate for central nervous system neurons. Neuron 5:627-637. CrossRef Medline

Faissner A, Pyka M, Geissler M, Sobik T, Frischknecht R, Gundelfinger ED, Seidenbecher C (2010) Contributions of astrocytes to synapse formation and maturation - Potential functions of the perisynaptic extracellular matrix. Brain Res Rev 63:26-38. CrossRef Medline

Ferhat L, Chevassus au Louis N, Jorquera I, Niquet J, Khrestchatisky M, Ben-Ari Y, Represa A (1996a) Transient increase of tenascin-C in immature hippocampus: astroglial and neuronal expression. J Neurocytol 25:53-66. CrossRef Medline

Ferhat L, Chevassus-Au-Louis N, Khrestchatisky M, Ben-Ari Y, Represa A (1996b) Seizures induce tenascin-C mRNA expression in neurons. J Neurocytol 25:535-546. CrossRef Medline

Fox K, Caterson B (2002) Neuroscience. Freeing the brain from the perineuronal net. Science 298:1187-1189. CrossRef Medline

Frischknecht R, Heine M, Perrais D, Seidenbecher CI, Choquet D, Gundelfinger ED (2009) Brain extracellular matrix affects AMPA receptor lateral mobility and short-term synaptic plasticity. Nat Neurosci 12:897-904. CrossRef Medline

Fuss B, Wintergerst ES, Bartsch U, Schachner M (1993) Molecular characterization and in situ mRNA localization of the neural recognition molecule J1-160/180: a modular structure similar to tenascin. J Cell Biol 120:12371249. CrossRef Medline

Galtrey CM, Fawcett JW (2007) The role of chondroitin sulfate proteoglycans in regeneration and plasticity in the central nervous system. Brain Res Rev 54:1-18. CrossRef Medline

Garcia-Alias G, Fawcett JW (2012) Training and anti-CSPG combination therapy for spinal cord injury. Exp Neurol 235:26-32.

Geissler M, Faissner A (2012) A new indirect co-culture set up of mouse hippocampal neurons and cortical astrocytes on microelectrode arrays. J Neurosci Methods 204:262-272. CrossRef Medline

Giamanco KA, Matthews RT (2012) Deconstructing the perineuronal net: cellular contributions and molecular composition of the neuronal extracellular matrix. Neuroscience 218:367-384. CrossRef Medline

Giamanco KA, Morawski M, Matthews RT (2010) Perineuronal net formation 
and structure in aggrecan knockout mice. Neuroscience 170:1314-1327. CrossRef Medline

Gogolla N, Caroni P, Lüthi A, Herry C (2009) Perineuronal nets protect fear memories from erasure. Science 325:1258-1261. CrossRef Medline

Gomes FC, Spohr TC, Martinez R, Moura Neto V (2001) Cross-talk between neurons and glia: highlights on soluble factors. Braz J Med Biol Res 34:611-620. CrossRef Medline

Goslin K, Banker G (1989) Experimental observations on the development of polarity by hippocampal neurons in culture. J Cell Biol 108:1507-1516. CrossRef Medline

Gundelfinger ED, Frischknecht R, Choquet D, Heine M (2010) Converting juvenile into adult plasticity: a role for the brain's extracellular matrix. Eur J Neurosci 31:2156-2165. CrossRef Medline

Haas CA, Rauch U, Thon N, Merten T, Deller T (1999) Entorhinal cortex lesion in adult rats induces the expression of the neuronal chondroitin sulfate proteoglycan neurocan in reactive astrocytes. J Neurosci 19:99539963. Medline

Haydon PG (2001) GLIA: listening and talking to the synapse. Nat Rev Neurosci 2:185-193. CrossRef Medline

Hedstrom KL, Xu X, Ogawa Y, Frischknecht R, Seidenbecher CI, Shrager P, Rasband MN (2007) Neurofascin assembles a specialized extracellular matrix at the axon initial segment. J Cell Biol 178:875-886. CrossRef Medline

Hsia AY, Malenka RC, Nicoll RA (1998) Development of excitatory circuitry in the hippocampus. J Neurophysiol 79:2013-2024. Medline

Ippolito DM, Eroglu C (2010) Quantifying synapses: an immunocytochemistrybased assay to quantify synapse number. J Vis Exp pii:2270.

Irintchev A, Rollenhagen A, Troncoso E, Kiss JZ, Schachner M (2005) Structural and functional aberrations in the cerebral cortex of tenascin-C deficient mice. Cereb Cortex 15:950-962. CrossRef Medline

John N, Krügel H, Frischknecht R, Smalla KH, Schultz C, Kreutz MR, Gundelfinger ED, Seidenbecher CI (2006) Brevican-containing perineuronal nets of extracellular matrix in dissociated hippocampal primary cultures. Mol Cell Neurosci 31:774-784. CrossRef Medline

Kaech S, Banker G (2006) Culturing hippocampal neurons. Nat Protoc 1:2406-2415. CrossRef Medline

Karus M, Denecke B, ffrench-Constant C, Wiese S, Faissner A (2011) The extracellular matrix molecule tenascin $\mathrm{C}$ modulates expression levels and territories of key patterning genes during spinal cord astrocyte specification. Development 138:5321-5331. CrossRef Medline

Kochlamazashvili G, Henneberger C, Bukalo O, Dvoretskova E, Senkov O, Lievens PM, Westenbroek R, Engel AK, Catterall WA, Rusakov DA, Schachner M, Dityatev A (2010) The extracellular matrix molecule hyaluronic acid regulates hippocampal synaptic plasticity by modulating postsynaptic L-type $\mathrm{Ca}(2+)$ channels. Neuron 67:116-128. CrossRef Medline

Kwok JC, Carulli D, Fawcett JW (2010) In vitro modeling of perineuronal nets: hyaluronan synthase and link protein are necessary for their formation and integrity. J Neurochem 114:1447-1459. CrossRef Medline

Kwok JC, Dick G, Wang D, Fawcett JW (2011) Extracellular matrix and perineuronal nets in CNS repair. Dev Neurobiol 71:1073-1089.

Lafon-Cazal M, Adjali O, Galéotti N, Poncet J, Jouin P, Homburger V, Bockaert J, Marin P (2003) Proteomic analysis of astrocytic secretion in the mouse. Comparison with the cerebrospinal fluid proteome. J Biol Chem 278:24438-24448. CrossRef Medline

Lander C, Zhang H, Hockfield S (1998) Neurons produce a neuronal cell surface-associated chondroitin sulfate proteoglycan. J Neurosci 18:174-183. Medline

Mahler M, Ferhat L, Gillian A, Ben-Ari Y, Represa A (1996) Tenascin-C mRNA and tenascin-C protein immunoreactivity increase in astrocytes after activation by bFGF. Cell Adhes Commun 4:175-186. CrossRef Medline

Matsui F, Nishizuka M, Yasuda Y, Aono S, Watanabe E, Oohira A (1998) Occurrence of a N-terminal proteolytic fragment of neurocan, not a $\mathrm{C}$-terminal half, in a perineuronal net in the adult rat cerebrum. Brain Res 790:45-51. CrossRef Medline

Mauch DH, Nägler K, Schumacher S, Göritz C, Müller EC, Otto A, Pfrieger FW (2001) CNS synaptogenesis promoted by glia-derived cholesterol. Science 294:1354-1357. CrossRef Medline

Michele M, Faissner A (2009) Tenascin-C stimulates contactin-dependent neurite outgrowth via activation of phospholipase C. Mol Cell Neurosci 41:397-408. CrossRef Medline
Morawski M, Brückner G, Arendt T, Matthews RT (2012) Aggrecan: Beyond cartilage and into the brain. Int J Biochem Cell Biol 44:690-693. CrossRef Medline

Morellini F, Sivukhina E, Stoenica L, Oulianova E, Bukalo O, Jakovcevski I, Dityatev A, Irintchev A, Schachner M (2010) Improved reversal learning and working memory and enhanced reactivity to novelty in mice with enhanced GABAergic innervation in the dentate gyrus. Cereb Cortex 20: 2712-2727. CrossRef Medline

Nikonenko A, Schmidt S, Skibo G, Brückner G, Schachner M (2003) Tenascin-R-deficient mice show structural alterations of symmetric perisomatic synapses in the CA1 region of the hippocampus. J Comp Neurol 456:338-349. CrossRef Medline

Perea G, Navarrete M, Araque A (2009) Tripartite synapses: astrocytes process and control synaptic information. Trends Neurosci 32:421-431.

Pizzorusso T, Medini P, Berardi N, Chierzi S, Fawcett JW, Maffei L (2002) Reactivation of ocular dominance plasticity in the adult visual cortex. Science 298:1248-1251. CrossRef Medline

Porto-Pazos AB, Veiguela N, Mesejo P, Navarrete M, Alvarellos A, Ibáñez O, Pazos A, Araque A (2011) Artificial astrocytes improve neural network performance. PLoS One 6:e19109. CrossRef Medline

Pyka M, Busse C, Seidenbecher C, Gundelfinger ED, Faissner A (2011a) Astrocytes are crucial for survival and maturation of embryonic hippocampal neurons in a neuron-glia cell-insert coculture assay. Synapse 65:41-53. CrossRef Medline

Pyka M, Wetzel C, Aguado A, Geissler M, Hatt H, Faissner A (2011b) Chondroitin sulfate proteoglycans regulate astrocyte-dependent synaptogenesis and modulate synaptic activity in primary embryonic hippocampal neurons. Eur J Neurosci 33:2187-2202. CrossRef Medline

Rathjen FG, Wolff JM, Chiquet-Ehrismann R (1991) Restrictin: a chick neural extracellular matrix protein involved in cell attachment co-purifies with the cell recognition molecule F11. Development 113:151-164. Medline

Rauch U, Zhou XH, Roos G (2005) Extracellular matrix alterations in brains lacking four of its components. Biochem Biophys Res Commun 328:608617. CrossRef Medline

Saghatelyan AK, Gorissen S, Albert M, Hertlein B, Schachner M, Dityatev A (2000) The extracellular matrix molecule tenascin-R and its HNK-1 carbohydrate modulate perisomatic inhibition and long-term potentiation in the CA1 region of the hippocampus. Eur J Neurosci 12:3331-3342. CrossRef Medline

Saghatelyan AK, Dityatev A, Schmidt S, Schuster T, Bartsch U, Schachner M (2001) Reduced perisomatic inhibition, increased excitatory transmission, and impaired long-term potentiation in mice deficient for the extracellular matrix glycoprotein tenascin-R. Mol Cell Neurosci 17:226-240. CrossRef Medline

Saghatelyan A, de Chevigny A, Schachner M, Lledo PM (2004) Tenascin-R mediates activity-dependent recruitment of neuroblasts in the adult mouse forebrain. Nat Neurosci 7:347-356. CrossRef Medline

Seidenbecher CI, Richter K, Rauch U, Fässler R, Garner CC, Gundelfinger ED (1995) Brevican, a chondroitin sulfate proteoglycan of rat brain, occurs as secreted and cell surface glycosylphosphatidylinositol-anchored isoforms. J Biol Chem 270:27206-27212. CrossRef Medline

Slezak M, Pfrieger FW (2003) New roles for astrocytes: regulation of CNS synaptogenesis. Trends Neurosci 26:531-535. CrossRef Medline

Sommer I, Schachner M (1981) Monoclonal antibodies (O1 to O4) to oligodendrocyte cell surfaces: an immunocytological study in the central nervous system. Dev Biol 83:311-327. CrossRef Medline

Susarla BT, Laing ED, Yu P, Katagiri Y, Geller HM, Symes AJ (2011) Smad proteins differentially regulate transforming growth factor-beta-mediated induction of chondroitin sulfate proteoglycans. J Neurochem 119:868-878. CrossRef Medline

Theodosis DT, Poulain DA, Oliet SH (2008) Activity-dependent structural and functional plasticity of astrocyte-neuron interactions. Physiol Rev 88:983-1008. CrossRef Medline

tom Dieck S, Sanmarti-Vila L, Langnaese K, Richter K, Kindler S, Soyke A, Wex H, Smalla KH, Kämpf U, Fränzer JT, Stumm M, Garner CC, Gundelfinger ED (1998) Bassoon, a novel zinc-finger CAG/glutaminerepeat protein selectively localized at the active zone of presynaptic nerve terminals. J Cell Biol 142:499-509. CrossRef Medline

Ullian EM, Christopherson KS, Barres BA (2004) Role for glia in synaptogenesis. Glia 47:209-216. CrossRef Medline

Wang D, Ichiyama RM, Zhao R, Andrews MR, Fawcett JW (2011) Chon- 
droitinase combined with rehabilitation promotes recovery of forelimb function in rats with chronic spinal cord injury. J Neurosci 31:9332-9344. CrossRef Medline

Weston MC, Nehring RB, Wojcik SM, Rosenmund C (2011) Interplay between VGLUT isoforms and endophilin A1 regulates neurotransmitter release and short-term plasticity. Neuron 69:1147-1159. CrossRef Medline

Wintergerst ES, Faissner A, Celio MR (1996) The proteoglycan DSD-1-PG occurs in perineuronal nets around parvalbumin-immunoreactive interneurons of the rat cerebral cortex. Int J Dev Neurosci 14:249-255. CrossRef Medline
Zhang Y, Anderson PN, Campbell G, Mohajeri H, Schachner M, Lieberman AR (1995) Tenascin-C expression by neurons and glial cells in the rat spinal cord: changes during postnatal development and after dorsal root or sciatic nerve injury. J Neurocytol 24:585-601. CrossRef Medline

Zhao RR, Muir EM, Alves JN, Rickman H, Allan AY, Kwok JC, Roet KC, Verhaagen J, Schneider BL, Bensadoun JC, Ahmed SG, Yáñez-Muñoz RJ, Keynes RJ, Fawcett JW, Rogers JH (2011) Lentiviral vectors express chondroitinase $\mathrm{ABC}$ in cortical projections and promote sprouting of injured corticospinal axons. J Neurosci Methods 201:228-238. CrossRef Medline 